\title{
Şanlıurfa, Balıklıgöl Kent Platosu'nun Ekolojik Tasarım Kapsamında Değerlendirilmesi
}

\author{
Hülya ÖZTÜRK TEL ${ }^{1 *}$ (iD), Elmas ERDOĞAN ${ }^{2}$ (D) \\ ORCID 1: 0000-0001-9277-9119 \\ ORCID 2: 0000-0002-4193-629X \\ ${ }^{1}$ Harran Üniversitesi, Şanlıurfa Teknik Bilimler Meslek Yüksekokulu, Mimari Restorasyon Bölümü, 63200, \\ Şanlıurfa, Türkiye. \\ ${ }^{2}$ Ankara Üniversitesi, Ziraat Fakültesi, Peyzaj Mimarlığı Bölümü, 06110, Ankara, Türkiye. \\ *e-mail: hulyaozturktel@gmail.com
}

Öz

Ekolojik tasarım; yerleşimlerin çevre üzerindeki etkisinin azaltılması, etkin kaynak kullanımı, etkin enerji kullanımı, etkin su kullanımı ve ekosistemin korunması gibi tasarım bileşenleri kapsamında gerçekleştirilen tasarımlardır. Ekolojik tasarım kriterlerine göre düzenlenen kent parkları, kentlilere doğa ile bütünleşme olanağı sağlar ve kent ekolojisini olumlu etkiler. Şanlıurfa geleneksel kent dokusunda yoğun bir kullanıma sahip olan Balıklıgöl Kent Platosu'da insanların doğa ile bütünleştikleri ekosisteme katkısı olan mikro klima düzenleyici bir alandır. Ancak bu alanın kent ekolojisine daha çok katkııının olması için gerekli iyileştirmelerin yapılması gerekmektedir. Bu araştırma kapsamında Şanlıurfa kent bütünü için önemli bir rekreatif alan olan Balıklıgöl Kent Platosu doğal ve kültürel özellikleri ile tanıtılarak ekolojik tasarım kriterlerine uygunluğu kapsamında değerlendirilmiştir. Bu doğrultuda araştırma alanı; etkin kaynak kullanımı, etkin enerji kullanımı, etkin su kullanımı kriterlerine uygunluk ve ekosistemin korunması açısından 4 ana kategoride değerlendirilerek kentsel ekolojik kazanımlara yönelik öneriler geliştirilmiştir.

Anahtar Kelimeler: Şanlıurfa, kent parkı, ekolojik tasarım, Balıklıgöl, enerji etkin peyzaj tasarımı

\section{Evaluation of Şanlıurfa, Balıklıgöl City Plateau in the frame of Ecological Design}

\begin{abstract}
The concept of ecological design coupromises sensitive criteria such as efficient use of environmental resources, energy efficient design, efficient use of water and the conservation of the ecosystem as the main design couparents in the design of human habitats and urban living environments. Urban parks, organized according to ecological design criteria, provide the citizens with the opportunity to integrate with nature and positively affect the urban ecology. Balıklıgol city park, which is used extensively in the traditional urban fabric of Şanlıurfa, is an area where people meet with nature contributing to the ecosystem. So ecological improvements should be made by paying attention to the ecological design criteria of this area. Within the scope of this research, Balıkligöl City Plateau, which is an important recreational area for the whole of Şanlıurfa city, will be introduced with its natural and cultural characteristics and evaluated in terms of its compliance with ecological design criteria. In this context, the research area; It is aimed to increase the gains of the city with the proposed regulations by evaluating
\end{abstract}

Citation/Atıf: Öztürk Tel, H. and Erdoğan, E. (2021). Şanlıurfa, Balıklıgöl Kent Platosu'nun ekolojik tasarım kapsamında değerlendirilmesi. Journal of Architectural Sciences and Applications, 6 (2), 564-585. DOI: https://doi.org/10.30785/mbud.956282 
them in 4 main categories namely effective use of resources, efficient use of energy, compliance with effective water use criteria and protection of the ecosystem.

Keywords: Şanlıurfa, city park, ecological design, ecological design, Balıklıgöl, energy efficient landscape design

\section{Giriş}

Çevre sorunları, nüfus artışı, yoğun yapılaşma ve turizm baskısı kentlerde açık yeşil alanların hızla azalmasına ve tahrip olmasına neden olmaktadır. Bu sorunlara çözümler getirmek, insanlara daha yaşanabilir bir dünya oluşturmak; ancak geçmişe ve geleceğe saygı duyarak ve geleneksel yapı kültüründen ders alarak planlanan ekolojik tabanlı tasarımlar ile mümkün olabilecektir. Bu bağlamda ekolojik tasarım; kentlerin yaşam kalitesini arttıran ve kentteki birçok probleme çözüm getiren bir tasarım anlayışıdır. Enerji tasarrufu sağlayan, dengeli yerel kaynak kullanımını teşvik ederek maksimum fayda sağlayan sürdürülebilir bir anlayıştır.

Ekolojik yaklaşım, alanın tasarımında yerel kaynakların kullanımına olanak sağlarken, alanın tesisi ve bakımında kaynak tüketimini en aza indiren uygulamalar ile etkin kaynak kullanımı sağlamaktadır (Cranz ve Boland, 2003).

Ekolojik tasarım; biyolojik çeşitliliği koruyan, hatta zenginleştirerek doğal yaşam çevreleri oluşturarak sürdürülebilir sistemlerin oluşturulmasıdır. Ekolojik tasarımın rolü; kentsel ortamda iklim değişikliği nesli tehlike altında olan türlerin ve değerli kaynakların kaybı gibi sorunların çözümüne destek olmak, kirliliği ve zararlanmayı azaltarak, enerji ve malzemeyi etkin kullanmaktır (Olsson, 2018).

Ekolojik tasarım; kültürel tercihleri ön planda tutan, yerel ve simgesel değerleri vurgulayan, doğal verilerle uyumlu bütünsel bir tasarım sürecidir (Girginer, 2006). Ekolojik anlayışla tasarlanan yeşil alanlar, ekolojik tasarım ilkelerine bağı kalarak, yerel habitatları ve bölgesel biyoçeşitliliği destekleyerek, kentsel ekosisteme entegre edilmiş doğal alanlardır (Cranz ve Boland, 2003).

Ekolojik tasarım kriterlerine uygun düzenlenmeyen alanlar da kaynaklar hızla tükenmekte ve sürdürülebilir olmaktan uzaklaşmaktadır.

Doğu'da Mardin, batıda Gaziantep, kuzeyde Adıyaman, kuzeydoğu'da Diyarbakır illeri ve güneyde Suriye ile sınırlandırılmış olan Şanlıurfa halk hikayelerin de ibrahim Peygamber ile ilgili anlatılara konu olmuş kutsal kentlerden biridir. M.Ö.10.000'lerden bu yana yerleşim yeri olan Şanlıurfa Assur, Med, Pers, Makedonya, Seleukos ile Osroene krallıkları sonrasında Roma, Bizans, Emevi, Abbasi ve Akkoyunlu hakimiyetinde kalmış, Hristiyanlık tarihi açısından da önemli bir yerleşme olmuştur. Osmanlı hakimiyetinden sonra Türk Kurtuluş Savaşı'nda gösterdiği başarı nedeni ile Şanlıurfa adını almıştır. Son dönemde gerçekleştirilen arkeolojik kazılar sonucunda elde edilen bulgular doğrultusunda, Anadolu uygarlıklar tarihi açısından önemi artmıştır. Çok tanrılı dinlerin yanı sıra pek çok peygamberin yaşadığı yer olan Şanlıurfa'da farklı dönem ve uygarlıklara ait çok sayıda taşınmaz kültür varlığı bulunmaktadır.

Anadolu ve Mezopotamya tarihi boyunca doğu ve batıyı birbirine bağlayan önemli ticaret yolları üzerinde bir odak noktası olan Şanlıurfa sahip olduğu doğal ve somut - soyut kültür varlıkları kapsamında özellikle kent merkezinin odağında konumlanan en önemli kentsel kamusal alan Balıklıgöl Kent Platosudur.

Bu araştırma kapsamında dünya ölçeğinde uygarlıklar tarihi açısından önemli odaklardan biri olan ve "Bereketli Hilal" olarak anılan topraklarda konumlanmış Şanlıurfa'nın geleneksel kent dokusunda önemli bir açık yeşil alan varlığı olan Balıklıgöl Kent Platosu'nun mevcut durumu saptanmıştır. Araştırma alanında yapılan etüd analiz çalışmaları doğrultusunda, alan ekolojik tasarım kriterleri açısından değerlendirilerek, koruma, peyzaj planlama ve tasarımı açısından öneriler geliştirilerek tartışımış; ekolojik tasarımın amaçları, etkin enerji kullanımı, etkin kaynak kullanımı, etkin su kullanımı ve ekosistemin korunması başlıkları altında incelenmiştir.

\section{Materyal ve Yöntem}

\subsection{Materyal}

Araştırmanın ana materyalini Şanlıurfa kent merkezinde konumlanan, Balıklıgöl Kent Platosu oluşturmaktadır (Şekil 1). Balıklıgöl Kent Platosu; yüzölçümü yaklaşık $77.600 \mathrm{~m}^{2}$ olup, Şanlıurfa 
geleneksel kent dokusunda geniş açık yeşil alana sahip kent parkı niteliğinde bir kentsel kamusal alandır (Şekil 2). Çalışmanın diğer materyalleri; konu ile ilgili olarak gerçekleştirilmiş olan bilimsel çalışmalar, her türlü araştırma, makale vb. yazılı ve görsel malzeme ile bu çalışmalardan elde edilen verilerin analizinden oluşmaktadır.

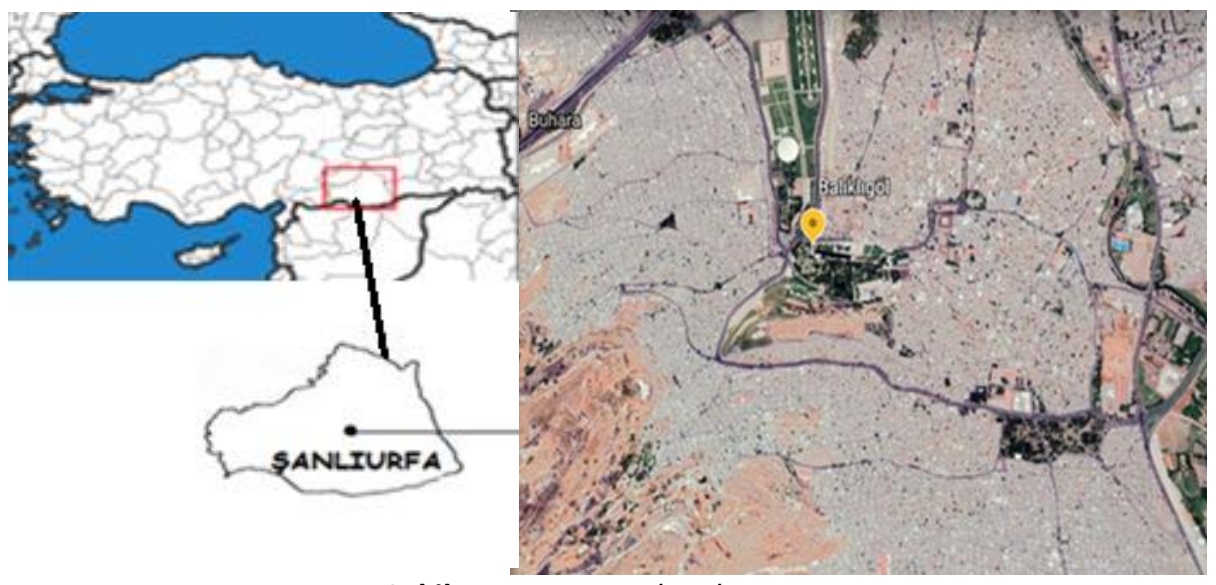

Şekil 1. Araştırma alanı konumu

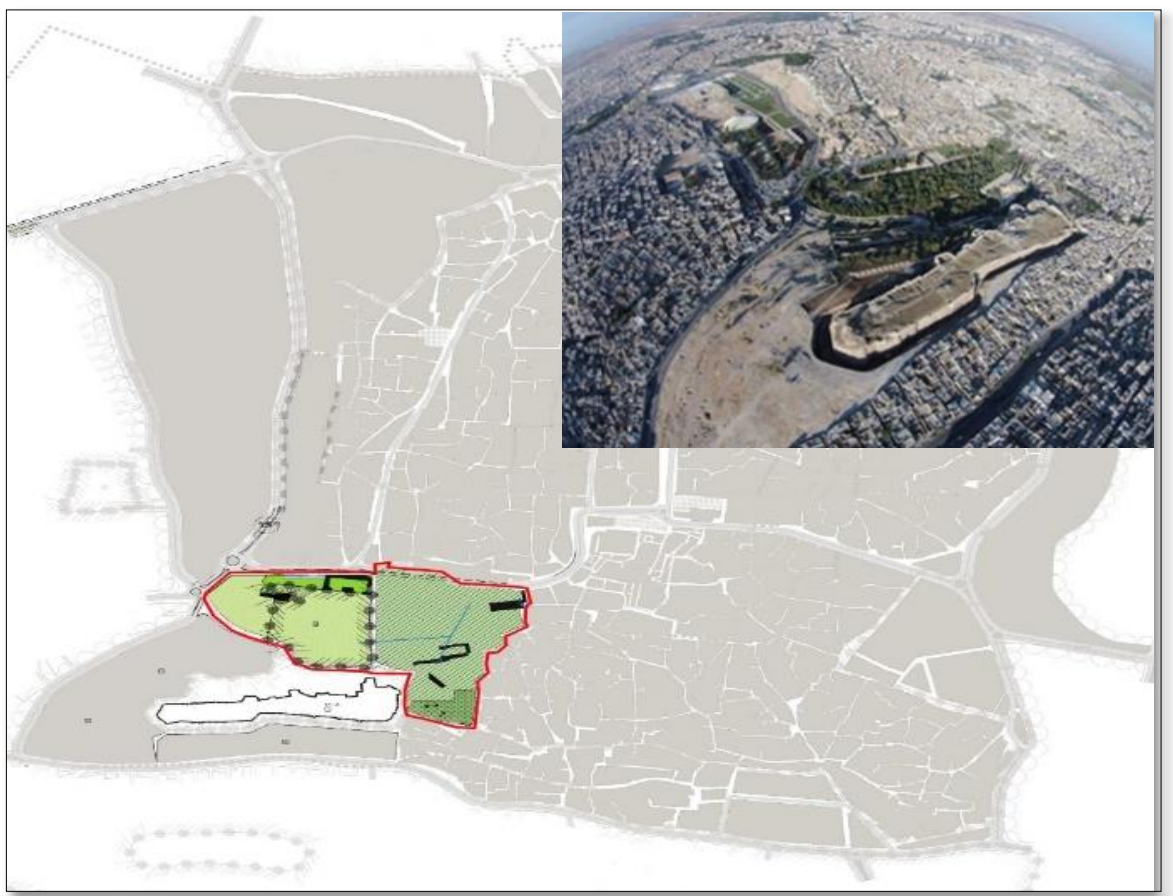

Şekil 2. Koruma Amaçlı İmar Planında çalışma alanı sınırı ve hava fotoğrafı (Şanlıurfa Büyükşehir Belediyesi, 2019)

\subsection{Yöntem}

Araştırma 3 aşamalı bir yöntem kapsamında gerçekleştirilmiştir.

\section{Aşama 1. Verilerin derlenmesi}

Araştırmanın ilk aşaması, araştırma alanı ve kuramsal temeller kapsamında gerçekleştirilmiştir. Literatür taramaları ile kent parkları, ekolojik tasarım ve ekolojik tasarım kriterlerin belirlenmesi ve araştırma alanıyla ilgili bulgu ve verilerin derlenmesi aşamasından oluşmaktadır.

\section{Aşama 2. Araştırma alanının ekolojik tasarım kriterleri kapsamında değerlendirilmesi}

Yapılan literatür araştırmalarından ekolojik tasarım kriterleri, araştırma alanına ilişkin doğal, kültürel ve ekolojik verilerin, ekolojik tasarım kriterleri açısından değerlendirilmesi yapılmıştır (Çizelge 1). Bu doğrultuda alanın özellikleri ve ekolojik tasarım kapsamında belirlenen kriterler ile araştırma alanına ilişkin ekolojik tasarım kriterleri değerlendirilmiştir. 
Çizelge 1 Ekolojik tasarım değerlendirilme kriterleri (Manisalı, 2011; Yüksek, 2008; Paulsen, 2001; Eryıldız 1995)

\begin{tabular}{|c|c|}
\hline \multicolumn{2}{|c|}{ Kent parklarının Ekolojik Tasarım Kriterleri Açısından Değerlendirilmesi } \\
\hline Ekolojik Tasarım Krit & \\
\hline ENERJI ETKIN TASARIM & $\begin{array}{l}\text { - } \quad \text { iklimlendirmenin doğal yöntemler ile sağlanması } \\
\text { - Yenilenebilir enerji kullanımı }\end{array}$ \\
\hline ETKIN KAYNAK KULLANIMI & $\begin{array}{l}\text { - } \quad \text { Yerel malzeme kullanımı / doğal bitki örtüsünden yararlanma } \\
\text { - } \quad \text { Dayanıklı yapı ürünlerinin ve yapı malzemelerinin kullanılması } \\
\text { - Geri dönüşümlü malzeme kullanımı }\end{array}$ \\
\hline ETKIN SU KULLANIMI & $\begin{array}{l}\text { - } \quad \text { Yöreye özgü bitki kullanımı } \\
\text { - } \quad \text { Geniş çim alanların optimal /etkin kullanımı } \\
\text { - } \quad \text { Yağmur suyu toplama sistemlerinin uygulanması } \\
\text { - } \quad \text { Yer altı su seviyesinin korunması } \\
\text { - } \quad \text { Su tüketiminde tasarruf sağlayan yöntemlerin kullanılması }\end{array}$ \\
\hline $\begin{array}{l}\text { EKOSISTEMIN VE DOĞAL } \\
\text { KAYNAKLARIN KORUNMASI }\end{array}$ & $\begin{array}{l}\text { - } \quad \text { Katı atıkların geri dönüşümü } \\
\text { - } \quad \text { Atık suların geri dönüşümü } \\
\text { - } \quad \text { Yaşam döngüsü boyunca az atık üreten malzemelerin kullanılması } \\
\text { - Mevcut bitki örtüsü, su varlığı, flora, fauna gibi yerel doğal } \\
\text { kaynakların korunması }\end{array}$ \\
\hline
\end{tabular}

\section{Aşama 3. Araştırma alanına ilişkin görüş ve önerilerin oluşturulması}

Bu aşamada ekolojik tasarım kriterleri doğrultusunda Balıklıgöl Kent Platosu'na ilişkin düzenlemeler yorumlanmış, ekolojik tasarım kapsamında elde edilen bulgu analiz ve sentezler sonucu öneriler geliştirilmiştir.

\section{Bulgular ve Tartışma}

\subsection{Balıklıgöl Kent Platosu Mevcut Durum ve Çevre Analizi}

Şanlıurfa gerek sahip olduğu zenginlikler doğal ve kültürel zenginlikler gerekse manevi ve somut olmayan kültürel dini ve sosyal değerleri bakımından önemli ve Anadolu'daki en eski yerleşmelerden biridir. Göbeklitepe'nin UNESCO Dünya Mirası listesine girmesi ile dünya ölçeğinde önemli olmuştur. Şanlıurfa kent kimliğinin önemli bir parçasını oluşturan Balıklıgöl Kent Platosu, UNESCO Dünya Mirası geçici listesine dahil edilen, geleneksel kent merkezindeki sınırlı sayıdaki yeşil alanların en önemli olanıdır. Balıklıgöl Kent Platosu yaklaşık olarak $77.600 \mathrm{~m}^{2}$ alanı ile geleneksel kent dokusu içinde konumlanmış en büyük kent parkıdır (Şekil 3). Bunun $60.000 \mathrm{~m}^{2}$ sini yeşil alan, $13.000 \mathrm{~m}^{2}$ sini ise sert zemin; $4600 \mathrm{~m}^{2}$ sini ise su alanı oluşturmaktadır.
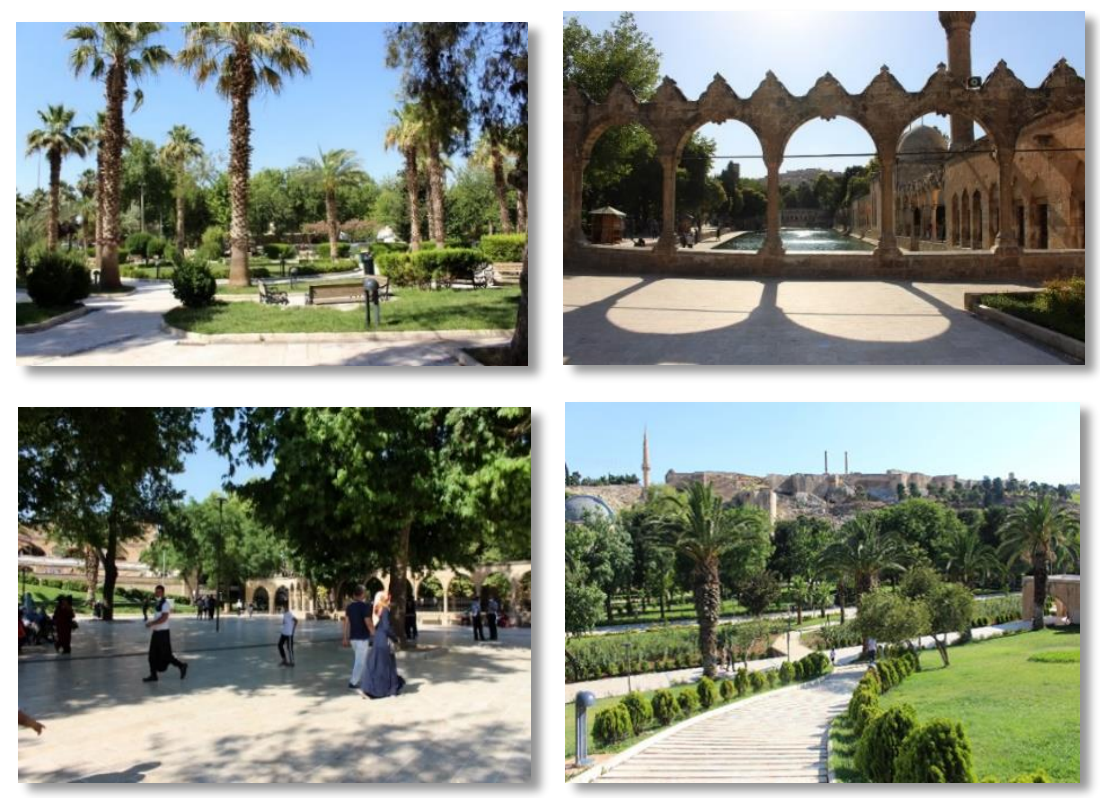

Şekil 3. Balıklıgöl kent platosu (Orijinal, 2020) 
Balıklıgöl Kent Platosu, tarihi ve dini önemi ile Şanlıurfa geleneksel kentinin simgesi ve odak noktasıdır. Balıklıgöl'ün tarihi M.Ö. 9500'lere dayanmaktadır. Balıklıgöl ve çevresinde saray, tapınak ve önemli yapılar yer almıştır. Balıklıgöl'ün bugün konumlandığı alanda Osrohene Krallığı M.Ö. yaklaşık 132'den 244'e kadar hüküm süren dönemde kralın yazlık, kışlık sarayı yer almış, Helenistik, Roma ve Doğu Roma dönemine ait de yapı kalıntıları yer almıştır (Ekinci ve Paydaş, 2008). Balıklıgöl ve çevresinde Türk kent kültürünün gerektirdiği cami, mescit, medrese gibi yapılar ile geleneksel konut alanları girift ve yoğun doku oluşturmaktadır. Balıklıgöl Kent Platosu'nda; Rızvaniye Camii, Hasan Paşa Cami, Halil Ür-Rahman Camii (Döşeme Camii), Mevlid-i Halil (Dergah) Camii, Halil-ür Rahman Gölü, Ayn-ı Zeliha Gölü ve bu yapılar arasında kalan meydanlar, su yüzeyleri ve açık yeşil alanlar yer almaktadır. Alanda bulunan Mevlid-i Halil (Dergâh) Cami'nin yanında yer alan mağarada Hz. İbrahim Peygamber'in doğduğuna inanılmaktadır. Alanda bulunan bu mağara ve göller kentin kutsal merkezini oluşturmakta olup, yoğun bir kullanıma sahiptir (Şanlıurfa Turizm Master Planı, 2019-2023). Alanın güneyinde Urfa Kalesi, güneybatısında kale eteği, kuzeyinde Haleplibahçe Arkeopark Alanı ve Kızılkoyun Mağaraları ve kuzey doğusunda ise Yenimahalle Neolitik Çağ Yerleşim Alanı bulunmaktadır (Şekil 4).

Balıklıgöl kent merkezinin güneybatısında konumlanan ve İbrahim Peygamberin ateşe atıldığında düştüğü yer olarak bilinen Balıklıgöl önemli bir hafıza mekanıdır. Yaklaşık 150m uzunluğunda ve 30m. genişliğinde olan Balıklıgöl'de efsanelere konu olan sazan balıkları bulunmakta ve kutsal sayılmaktadır. Çevresinde yer alan taşınmaz kültür varlıkları ile kentin en aktif kullanılan kamusal alanı olarak işlev görmektedir.

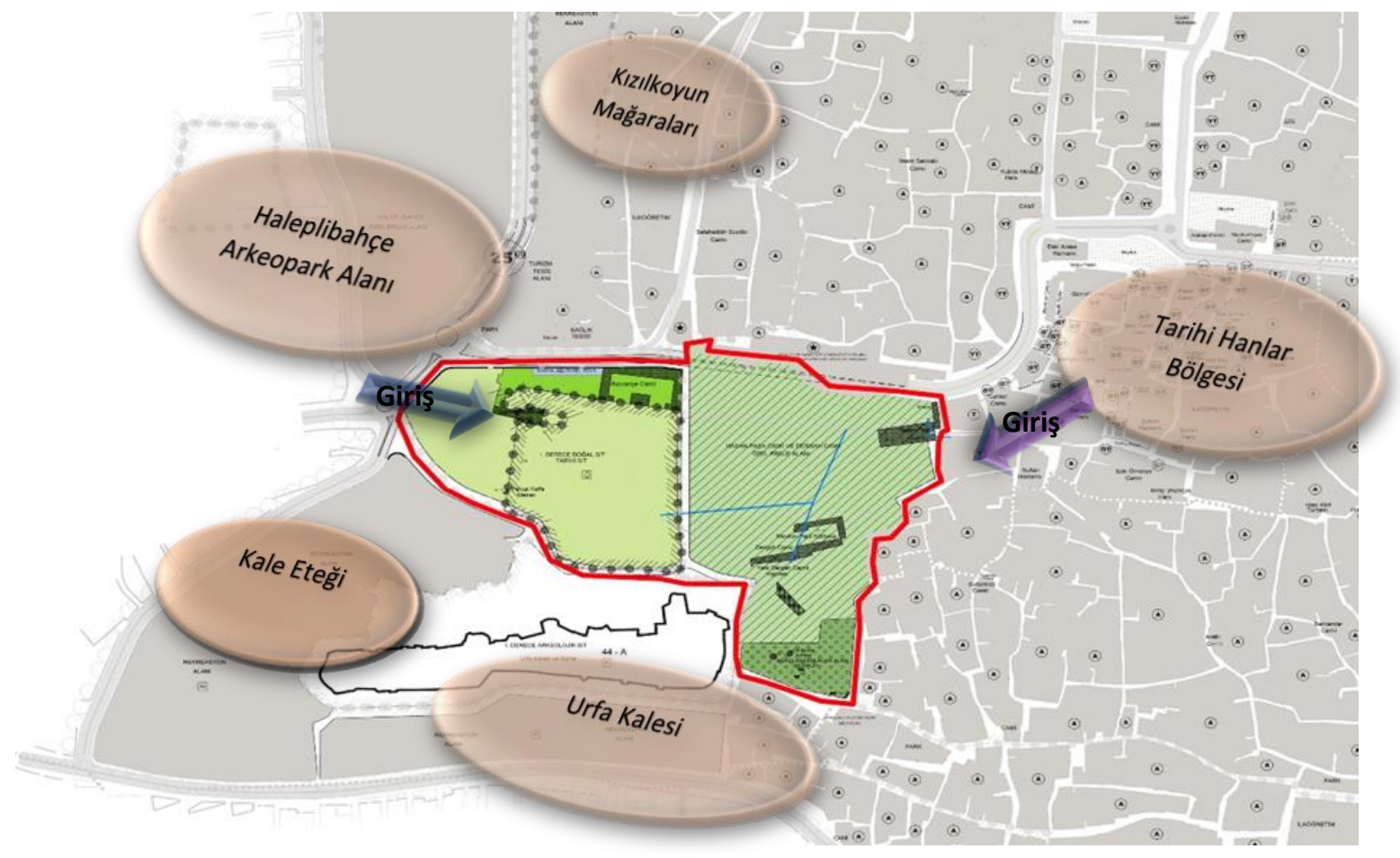

Şekil 4. Balıklıgöl kent platosu ve yakın çevresi (Orijinal, 2021)

Balıklıgöl' e 1996-2000 yılları arasında "Dergâh ve Balıklıgöl Çevre Düzenleme Projesi" gerçekleştirilerek kentin tarihi kimliğinin korunması, yerel halkın kültürel ve sosyal gelişimine katkı sağlanması hedeflenmiştir (Şekil 5). Dış cepheler geleneksel Urfa taşı ile kaplanmış, 200 araçlık otopark, tünel, 95 adet dükkân, 14 adet büro, 53 odalı otel, 3 adet çay salonu, 2 adet lokanta, tuvalet, abdest alma yerleri inşa edilerek, tarihi kent kimliği, geleneksel kültür ve taşınmaz kültür varlıklarına vurgu yapılması amaçlanmıştır.

Balıklıgöl Kent Platosu ve çevresinde, somut ve soyut kültürel değerler ile geleneksel doku hala mevcut olup, genel anlamda Urfa taşından inşa edilmiş geleneksel yapıların, avlulu plan ve cephe özelliklerinin bozulmadan bugüne ulaştığını söylemek mümkündür. 


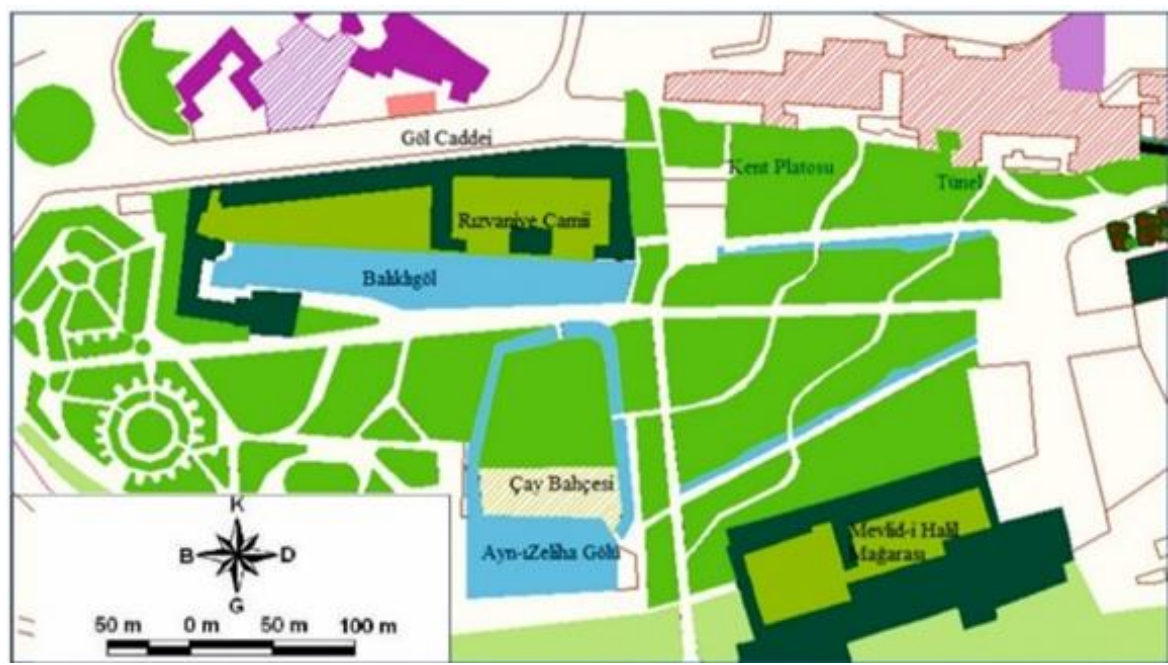

Şekil 5. Balıklıgöl kent platosu çevre düzenlemesi vaziyet planı (Orijinal, 2014)

Balıklıgöl Kent Platosu ve yakın çevresinde; yoğun nüfus baskısı nedeni ile Şanlıurfa 2017 Tüik verilerine göre \%22'lik yüksek bir nüfus artışının getirdiği baskı, terk edilme ve fiziksel eskime gibi durumlar ile Suriye'den yoğun göç sonucu alanın çevresinde yer alan harabe durumdaki geleneksel konut alanlarında yaşam kalitesi ve konfor koşulları niteliğini yitirmekte, alanda nüfus ve kullanım yoğunluğun artmasına neden olmaktadır (Karacadağ Kalkınma Ajansı, 2018). Bu durum da çevresel ve koruma sorunlarının oluşmasını beraberinde getirmektedir. Artan trafik yoğunluğu ve bu yoğunluğun Balıklıgöl Kent Platosu'nun sınırında yer alması ile oluşan titreşim ve hava kirliliği ekolojik anlamda bozulmaya ve yaşam standardının düşmesine neden olmaktadır.

\subsection{1. İklim ve topografya}

Karasal iklimin hüküm sürdüğü bölgede Köppen iklim sınıflandırılmasına göre Akdeniz iklimi de görülmektedir. Yazlar kurak ve sıcak, kış mevsimi ise yağışlı ve kısmen ılıman geçmektedir (Güzel, 2020).

Balıklıgöl Kent Platosu; Tel Fettur Tepesi ile Damlacık Tepesi arasında kalan vadi tabanında yer almaktadır. Alanın güneyinde Damlacık Tepesi'nin bulunduğu yerde dik ve sarp kayalıklar şeklinde uzanan alanda Urfa Kalesi yer almaktadır.

\subsubsection{Bitki örtüsü ve yaban yaşamı}

Balıklıgöl Kent Platosunun; $77.600 \mathrm{~m}^{2}$ alana sahip olup, bunun $60.000 \mathrm{~m}^{2}$ gibi büyük bir bölümünü yeşil alanlar oluşturmaktadır. Alan yoğun bir bitki dokusu ile kaplı olup, geniş çim alanlar da oldukça fazladır. 2014 yılı itibari ile Balıklıgöl'de bulunan bitki varlığı ve sayıları Çizelge 2'de verilmiştir.

Çizelge 2. Araştırma alanında bulunan mevcut bitki türleri

\begin{tabular}{lll}
\hline Latince Adı & Türkçe Adı & Adet \\
\hline Geniş yapraklılar & & 74 \\
\hline Trachycarpus fortunei Wendl. & Rüzgar gülü & 17 \\
\hline Elaeagnus commutata L. & İğde & 82 \\
\hline Platanus orientalis L. & Doğu çınarı & 5 \\
\hline Salix babylonica L. & Salkım sögüt & 2 \\
\hline Albizzia jülibrissin Durazz. & Gülibrişim & 12 \\
\hline Ficus carica L. & İcir & 112 \\
\hline Morus alba L. & Dut & 1 \\
\hline Morus alba 'Pendula' & Sarkı dut & 7 \\
\hline Eriobotrya japonica & Malta eriği, Yeni dünya \\
\hline Phoenix dactylifera L. & Hurma & 55 \\
\hline Magnolia grandiflora L. & Manolya & 5 \\
\hline Lagerstroemia indica L. & Oya ağacı & 22 \\
\hline Prunus cerasifera 'Atropurpurea' Rehd. & Kırmızı erik & 2 \\
\hline Celtis glabrata L. & Çitlenbik & 2 \\
\hline Robinia pseudoacacia L. & Yalancı akasya & 38 \\
\hline Populus tremula L. & Titrek kavak & 5 \\
\hline Acer campestre & Ova akçaağacı & 5 \\
\hline Melia azaderach L. & Tesbih ağacı & 5 \\
\hline
\end{tabular}




\begin{tabular}{|c|c|c|}
\hline Aesculus hippocastanum & At kestanesi & 1 \\
\hline Tilia tomentosa Moench. & Gümüşi ıhlamur & 3 \\
\hline Eucalyptus camaldulensis Dehnh. & Okaliptus & 2 \\
\hline Cercis siliquastrum $\mathrm{L}$. & Erguvan & 13 \\
\hline Robinia pseudoacacia 'Umbraculifera' & Top akasya & 7 \\
\hline Sophora japonica L. & Sofora & 3 \\
\hline Ailanthus altissima & Kokarağaç & 2 \\
\hline Crataegus monogyna Lindm & Alıç, Dağ elması & 5 \\
\hline Ficus elastica & İskenderun kauçuğu & 3 \\
\hline \multicolumn{3}{|l|}{ İğne Yapraklılar } \\
\hline Pinus silvestris L. & Sarıçam & 18 \\
\hline Pinus nigra Arnold. & Karaçam & 25 \\
\hline Pinus brutia Henry. & Kızılçam & 105 \\
\hline Cedrus libani A. Rich. & Lübnan sediri & 12 \\
\hline Cupressus sempervirens L. & Adi servi & 5 \\
\hline Juniperus communis & Adi ardıç & 2 \\
\hline Cupressus arizonica 'Glauca' Greene. & Arizona servisi & 12 \\
\hline \multicolumn{3}{|l|}{ Ağaçcık, Çalı } \\
\hline Jasminum officinale L. & Beyaz çiçekli yasemin & 10 \\
\hline Prunus laurocerasus L. & Karayemiş & 5 \\
\hline Lonicera japonica $L$. & Hanımeli & 30 \\
\hline Hedera helix $L$. & Kaya sarmaşı̆̆ 1 & 10 \\
\hline Juniperus horizontalis Mnch & Yayılıcı ardıç & 3 \\
\hline Forsythia intermedia Zab. & Altın çanak & 16 \\
\hline Thuja orientalis 'Pyramidalis' & Piramit mazı & 13 \\
\hline Punica granatum 'Nana' L. & Süs nar1 & 36 \\
\hline Cycas revoluta Thunb. & Yalancı palmiye & 2 \\
\hline Daphne mezereum L. & Defne & 12 \\
\hline Olea europaea L. & Zeytin & 1 \\
\hline Callistemon citrinus Stapf. & Firça çalısı & 20 \\
\hline Thuja orientalis & Doğu mazısı & 120 \\
\hline Nerium oleander L. & Zakkum & 107 \\
\hline Euonumus japonica L. & Taflan & 124 \\
\hline Pittosporum tobira L. & Y1ldız çalısı & 14 \\
\hline Pyracantha coccinea Roem. & Ateş dikeni & 21 \\
\hline Hedera helix L. & Kaya sarmaşı̆̆ 1 & 20 \\
\hline Ligustrum japonicum Thunb. & Adi kurtbağrı & 200 \\
\hline Rosa sp. & Gül & 300 \\
\hline
\end{tabular}

Yaban yaşamı açısından alanda bulunan Halil-ür Rahman Gölü’nde sazangiller familyasından; Capoeta umbla (Karabalık), Carasobarbus luteus (Iripullu sazan), Leuciscus cephalusorientalis (Tatlısu kefali), Alburnus caeruleus (Gümüş balığı), Garra rufa obtusa (Kaya balığı) türleri yaşamaktadır (Şanlıurfa Büyükşehir Belediyesi, 2019).

\subsubsection{Balıklıgöl Kent Platosu'ndaki sit alanları ve su varlığı}

Balıklıgöl kent platosu; "Tarihi ve 1. Derece Doğal Sit” ve özel proje alanından oluşmaktadır. Halil-ür Rahman Gölü ve Ayn- Zeliha Gölü'nün bulunduğu alan "Tarihi ve 1. Derece Doğal Sit” alanı olup, Hasan Paşa Cami ve Mevlid-i Halil (Dergâh) Camii özel proje alanı olup, dini yapılar korunarak, alan rekreasyonel amaçlı düzenlenmiştir (Şekil 6). 


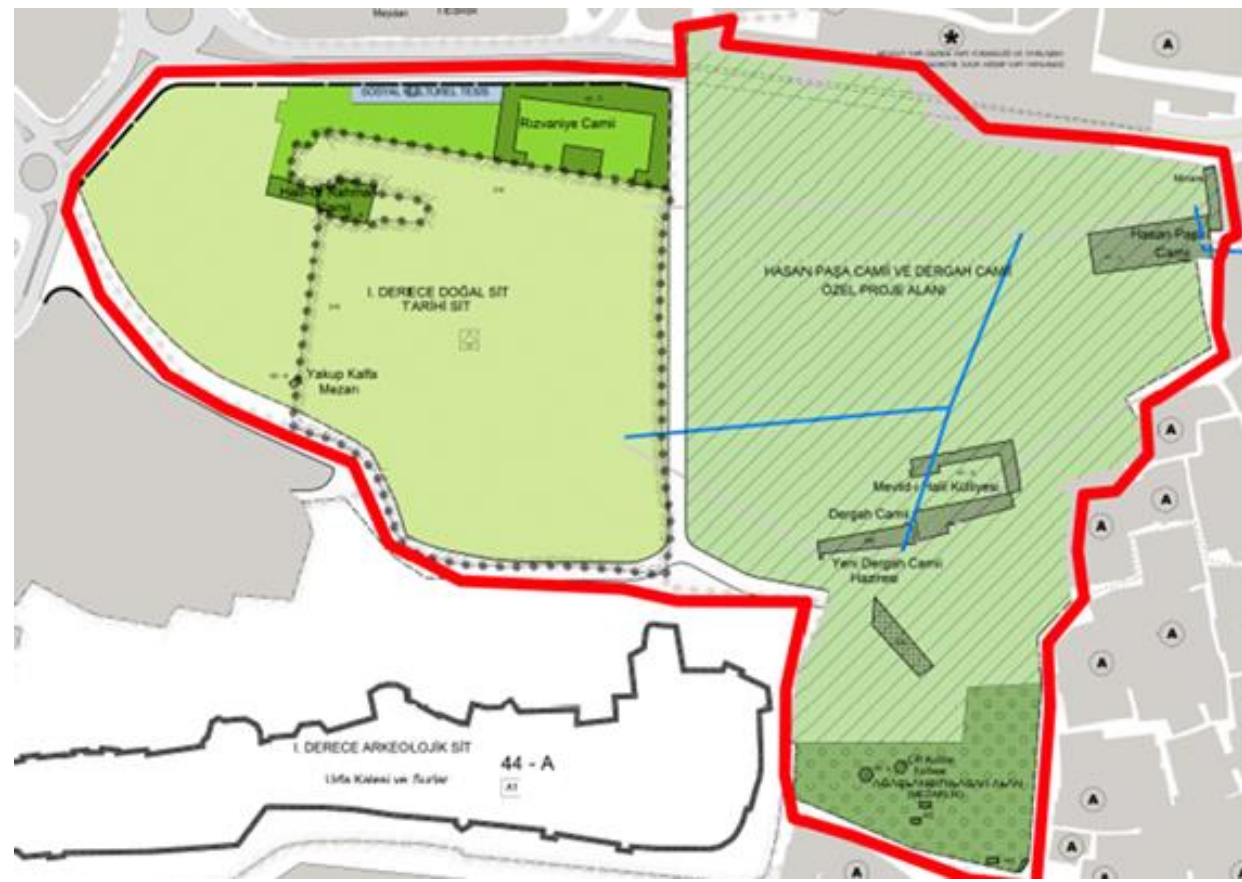

Şekil 6. Balıklıgöl kent platosu’ndaki sit alanları ve su kanalları fotoğrafı (Şanlıurfa Büyükşehir Belediyesi, 2019)

Balıklıgöl kent platosunun içinde yer alan; Halil-ür Rahman ve Ayn Zeliha Gölleri; batıdan şehre giren Daysan Nehri ile beslenerek kanallar ile doğu yönünde akmaktadır. Halil-ür Rahman Gölü; Rızvaniye Cami'nin önünde yer alan 150 m uzunluk ve 30 m genişliğindedir (Gelener, 2011).

Araştırma alanında yer alan bir diğer önemli göl ise Ayn-ı Zeliha Gölü'dür. Rivayetlere göre, Hz. Ibrahim ateşe atılmasından sonra Nemrut'un kızı Zeliha'nın da kendini ateşe attığı yerde oluşan göldür. Yaklaşık $30 \mathrm{~m}$ genişliğinde ve $50 \mathrm{~m}$ uzunluğundadır (Şekil 7).

Halil-ür Rahman Gölü ile aynı özelliklere sahip olan Ayn-ı Zeliha Gölü de yine çevresindeki karstik kaynaklardan beslenmektedir (Gelener, 2011).
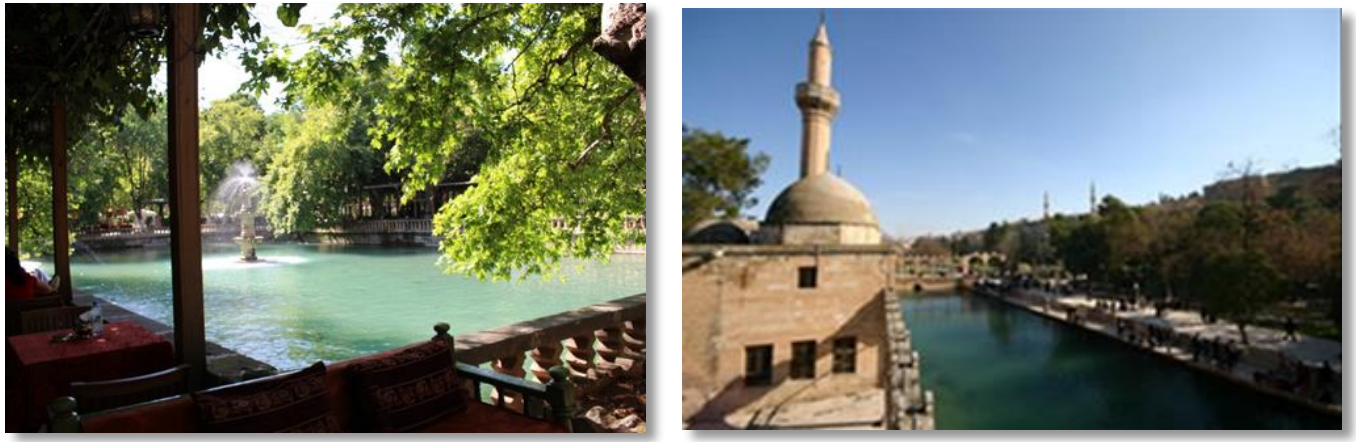

Şekil 7. Ayn Zeliha Gölü (solda), Halil-ür Rahman Gölü (sağda).

Halil-ür Rahman ve Ayn-ı Zeliha göllerini besleyen başlıca kaynak tarih boyunca kentin önemli akarsu kaynağı olan ve güneyde şehri çevreleyen Daysan Nehri; Halil-ür Rahman ve Ayn-ı Zeliha gölünü besleyerek doğuya doğru akmaktadır. Su; doğudaki surlarda açılmış bir su kapısından sur dışına çıkmaktadır (Şahinalp, 2005). Daysan Nehri özellikle kış ve bahar aylarında taşkınlara neden olmasından dolayı Bizans İmparatoru Jüstinyen bendini inşa ederek nehrin yönü değişerek sur içinden akan su sur dışından akıtılmıştır. Büyük bölümü Balıklıgöl Kent Platosu'nda bulunan su yolu 2010 yılında "Halilürrahman Suyu Tahliye Kanalı" olarak tescillenmiştir. Halilürrahman ve Ayn Zeliha göllerinden kanallarla Mevlid-i Halil Camii (Dergâh Cami) avlusu ve buradan Hasan Paşa Camisi'ne ulaşmaktadır (Şekil 8). 

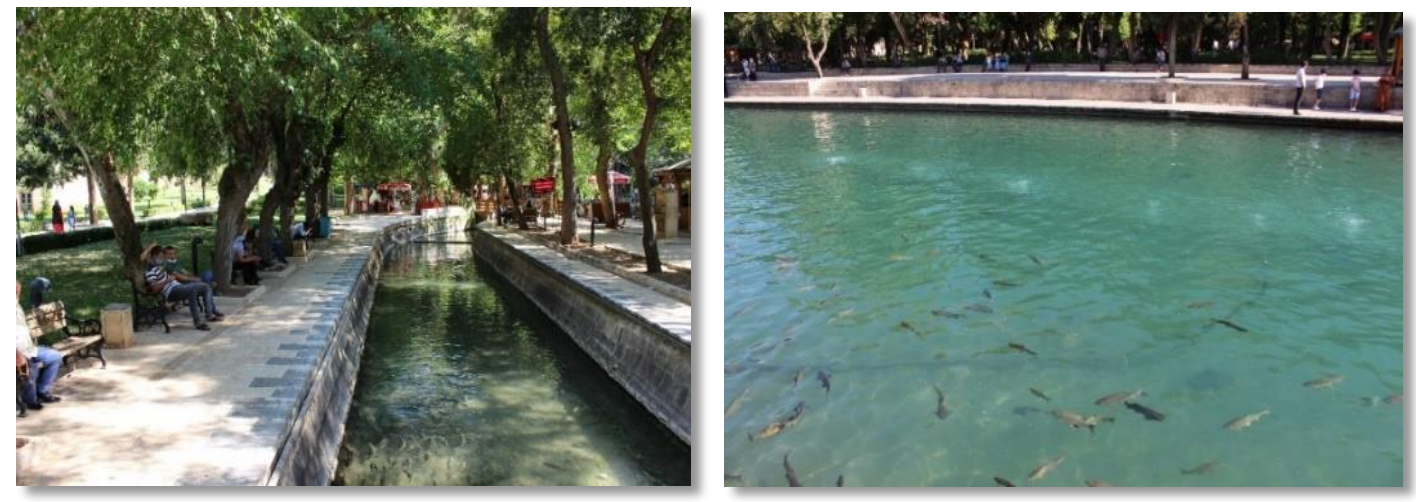

Şekil 8. Halil-ür Rahman Gölü ve su kanalları (Orijinal, 2021)

\subsection{Kent Parklarının Ekolojik Tasarım Kapsamında İrdelenmesi}

Şanlıurfa kenti içinde yer alan açık yeşil alanlar; havanın arıtılması, su kütlesinin saflaştırılması, toprağın arındırılması, kentsel alanda mikroklimanın iyileştirilmesi, gürültünün azaltılması ve havadaki bakteri sayısının azaltılmasında etkili olmakta; atmosferdeki kirliliğin \%80'ini filtreleyebilmektedir (Ni, 2019).

Kentlerdeki açık yeşil alanların sürdürülebilirliği ancak doğru ve etkin bir ekolojik tasarım yaklaşımı ile Çevreye daha az zarar vermeye yönelik çözüm arayışları, kentsel mimari ve peyzaj tasarımı ekolojik yaklaşımlara doğru yöneltmektedir. Ekolojik ve sürdürülebilir tasarım kriterleri olarak adlandırılan bu yöntemler, enerji etkin tasarım, etkin kaynak kullanımı, etkin su kullanımı ve ekosistemin korunması konularını kapsamaktadır.

\subsubsection{Enerji etkin tasarım}

Enerjinin etkin bir şekilde kullanılması iklimlendirmenin doğal yöntemlerle sağlanması ve yenilenebilir enerji kullanımı ile mümkündür. Peyzaj mimarlığı ve peyzaj tasarımı açısından değerlendirildiğinde yapısal ve bitkisel tasarımın bu anlamda doğru ve etkin kullanımı gündeme gelmektedir.

\subsubsection{1. İklimlendirmenin doğal yöntemler ile sağlanması}

Yeşil alanlar ve su öğeleri havadaki istenmeyen ısı yükünü almakta ve doğal iklimlendirme sağlamanın yanı sıra mikroklima yaratmada da rol oynamaktadır. Soğuk bölgelerde yapıların düzlük alanlar ile vadilere düzlüğe, vadiye, ılıman yerlerde yamaçlara, sıcak yerlerde ise sırtlardaki düzlüklere yerleştirilmesi gerekmektedir. Yapılardaki yeşil çatı uygulamaları; havadaki kirletici emisyon miktarını azaltırken nem oranını da dengelemektedir. (Oral ve Manioğlu, 2005). Sıcak-kuru iklim bölgelerinde neme gereksinim bulunmakta ve vadi tabanına yerleşilmesi en uygun ekolojik çözüm olarak ortaya çıkmaktadır. Vadi tabanı yamaçlara oranla düz yüzey olduğu için güneş ışınımının ısıtıcı etkisi daha düşük olmaktadır.

Sıcak kuru iklime sahip yörelerde yerleşim dokusu düşük yoğunluklu yapılaşma kapsamında, çok parçalı ve avlulu olarak tasarlanmalıdır. Yapıyı oluşturan mekanların avlu ile bağlantılı düşünülmesi ve yapının odak noktasında avlunun konumlandırıması yapı için mikro klima oluşturmak açısından kolaylık sağlayacaktır. Yapı gereci olarak iyi yalıtım sağlayan taş malzeme kullanımı, yapı cephelerinin ise malzemenin kendi rengi veya açık renk olarak tasarlanması kışın sıcak yazın serin ortamların yaratılmasını sağlayacaktır.

\subsubsection{Yenilenebilir enerji kullanımı}

Aydınlatma, sulama ve ulaşımda yenilenebilir enerji kaynakları kullanılmalıdır. Bu güneş/solar, rüzgar, su gibi enerji kaynakları kullanılmalıdır. Peyzaj tasarımı çalışmaları kapsamında ise aydınlatmada solar enerjiden yararlanmalı; sulamada ise yağmur suyu hasadı yapılmalı, suya dayanıklı doğal bitki türleri ve kurakçıl peyzaj uygulamaları ile etkin kaynak kullanımı sağlanmalıdır.

\subsubsection{Etkin kaynak kullanımı}

Etkin kaynak kullanımı; yerel kaynak ve dayanıkı malzeme kullanımı, geri dönüşümlü malzeme kullanımı ile sağlanabilmektedir. 


\subsubsection{Yerel kaynak ve dayanıklı malzeme kullanımı}

Yerleşim alanı ve yakın çevresinde bulunan yerel kaynakların kullanımı ile o bölgede bulunmayan, dolayısıyla temin edilmesi de zor olan başka bölgelerdeki kaynaklara yapılacak olan müdahale engellenerek etkin kaynak kullanımı sağlanabilmektedir. Yapılarda dayanıklı malzeme kullanımı ile hammaddeye kısa zaman aralıkları ile müdahalelerde bulunulmayarak kaynak etkinliği sağlanabilecektir. Ayrıca kaynakların tasarruflu bir şekilde kullanılması ile doğaya olan müdahale olabildiğince alt seviyede tutularak, dolayısıyla yapılaşmanın çevreye zarar vermesi büyük oranda azaltılabilmektedir (Manisalı, 2011).

\subsubsection{Geri dönüşümlü malzeme kullanımı}

Yeniden değerlendirilme imkânı olan yapısal atıkların çeşitli fiziksel ve/veya kimyasal işlemlerden geçirilerek ikincil hammaddeye dönüştürülerek tekrar üretim sürecine dahil edilmesi sonucunda geri dönüşümlü malzemeler elde edilmektedir. Geri dönüşümlü malzeme kullanımı aynı zamanda atık miktarını da azaltarak, kirlenmeyi de önlemektedir (Saltabaş ve diğerleri, 2012).

\subsubsection{Etkin su kullanımı}

Insan yaşamı ve doğal çevre için büyük önem taşıyan su yenilenebilir bir kaynak olmasının yanı sıra tükenme tehlikesi ile de karşı karşıyadır. Yöreye özgü bitki kullanımı doğal bitki örtüsünden yararlanma, geniş çim alanların optimal/etkin kullanımı, yağmur suyu toplama sistemlerinin uygulanması, Yer altı su seviyesinin korunması ve su tüketiminde tasarruf sağlayan yöntemlerin kullanılması ile mümkün olabilmektedir.

\subsubsection{Yöreye özgü bitki kullanımı}

Peyzaj düzenlemelerinde az su isteyen veya o bölgeye özgü bitkilerin kullanımı, su tüketimini azaltan etkili bir yöntemdir. Özellikle yıllık yağış miktarının düşük olduğu yörelerde, kuraklığa dayanıklı, sulama istemeyen yöresel bitkilerin kullanıldığı peyzaj tasarımları sayesinde su tüketimi azaltıldığı gibi, bakım maliyetleri de düşürülmekte; daha ekonomik sürdürülebilir tasarım uygulamaları gerçekleştirilebilmektedir. Ekolojik tasarım, mevcut yerel bitki türlerinin korunmasını ve onarılmasını gerektirmektedir (Yang, 2017).

\subsubsection{Geniş çim alanların optimal/etkin kullanımı}

Sıcak kuru iklim bölgelerinde yapılan düzenlemelerde geniş çim alanların geniş yapraklı ve gölge yapan ağaçlar ile ve yörede doğal yayılım gösteren kuraklığa dayanıklı yer örtücü türlerin kullanımı su tüketimini azaltırken, Isı adası oluşumunu da engellemektedir.

\subsubsection{Yağmur suyu toplama sistemlerinin uygulanması}

Yağmur suyunun toplanarak uygun alanlarda yeniden kullanımı su korunumunda yararlar sağlamaktadır. Yağmur suyunu toplayacak sistem, o bölgeye düşen yıllık yağış miktarı ve toplanacak suyun kullanım amacına uygun olarak tasarlanmalıdır.

Açık yeşil alanlarda yağmur suyunun toplandığı; biyolojik yapay havuzlar (suyu kendi kendine temizleyen bitki kullanımlı havuz; sazlıklar vb.), göletler ya da su kanalları oluşturulmalıdır. Yağmur suyu toplama sistemleri kolaylıkla kurulabilmekte, kullanım ve bakım açısından kullanıcılara kolaylık sağlamakta, oluşacak su tasarrufu ile ülke ekonomisine büyük katkı sağlarken kaynaklarda etkin kullanılmaktadır.

Yağmur bahçesi, yağmur sularının herhangi bir işleme tabi tutulmadan doğrudan yönlendirildiği ve üzerinde doğal bitkilerin yetiştirilebildiği sığ çukur alanlardır. En önemli işlevleri yağış sonrası oluşan yüzey akışı ile birlikte gelen suyun toplanması ve biyolojik arıtma yöntemleriyle arıtılarak su kalitesinin iyileştirilmesidir (Coşkun Hepcan 2019, Jaber ve diğerleri, 2012). Yağmur bahçesinde biriken su, yavaş bir şekilde toprağa süzülmektedir. Yağış sonrası yüzey akış miktarının azaltılması, yeraltı suyu beslemesinin iyileştirilmesi ve kirliliğin sulara ulaşmadan tutulması amacı ile kullanılan yağmur bahçeleri; yerel yönetimler için son derece basit ve maliyetsiz bir yöntemdir (Şekil 9). Killi toprak ve çakıllarla kapasitesi arttırılan yağmur bahçeleri taşkın ve sel baskınlarını da engellemektedir (Reed ve 
Stibolt, 2018; Jaber ve diğerleri, 2012). Taşkın alanları belirlenerek tasarımda bu alanların koruma altına alınması taşkın riskini azaltacaktır.
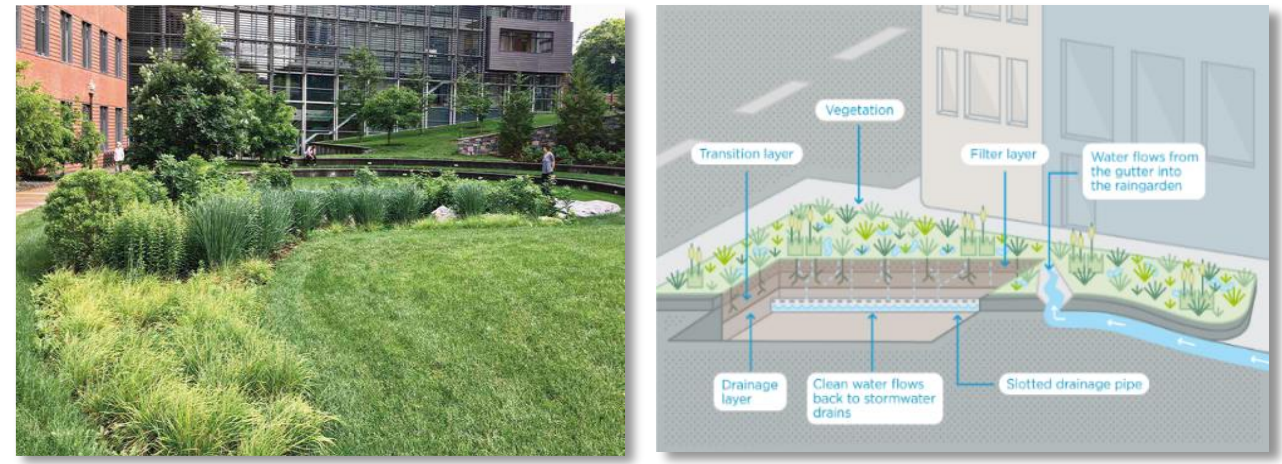

Şekil 9. Massachusetts Üniversitesi yağmur bahçesi (Reed ve Stibolt, 2018; Urbanwater, 2021)

\subsubsection{Yer altı suyunun korunması}

Kaldırım ve yaya yolları gibi sert zeminlerde ve döşeme kaplamalarında yüzeylerde geçirimli malzemelerin kullanılması ile yağmur ve yüzey suyunun kontrollü bir şekilde akması ve yer altı geçiriminin sağlanarak yer altı sularının seviyeleri korunmalıdır.

Alt yapı sistemlerinin yeterli olmaması nedeni ile biriken yağmur suları sel taşkınlarına dönüşebilmekte, geçirimsiz kaldırımlar suyun emilimini engellemekte ve yer altı suları beslenmemekte ve yenilenememektedir (Jayasuriya ve diğerleri, 2007) (Şekil 10).

Su akışının belirli bir eğimle yeşil alanlara ya da yağmur bahçelerine yönlendirilmesi sağlanmalıdır. Süzülen su yer altı suyunu arttırmakta bu durum şehrin alt yapı kanalizasyon sistemlerindeki su basıncının azaltılmasını sağlamaktadır. Yağış suyunu bordür açıklıklarından içine alacak şekilde yol ve kaldırım kenarlarında oluşturulan yağış suyu bitki şeritleri yüzey akış suyu kontrolü sağlarken, sızdırma ve filtreleme işlevlerini de görmektedir (Coşkun Hepcan, 2019, Jayasuriya ve diğerleri, 2007) (Şekil 11).

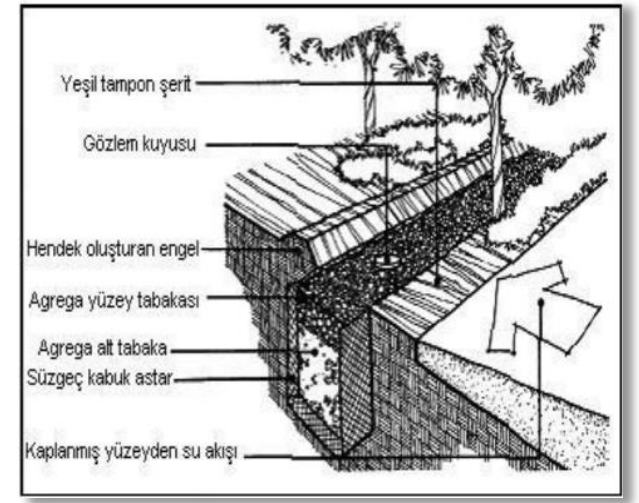

Şekil 10. Süzülme çukuru detayı (Manisalı, 2011)

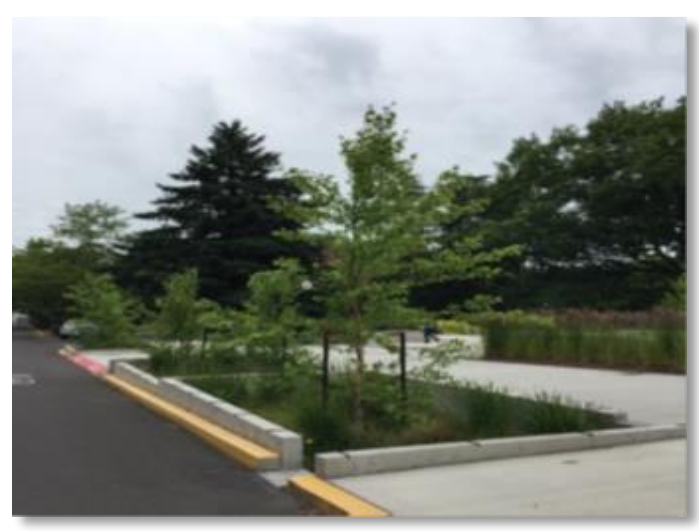

Şekil 11.Yağış suyu bitki şeridi örneği (Coşkun Hepcan, 2019) 
Özellikle yaşanabilecek taşkınlarda; yağmur bahçelerinin kullanılması, taşkınlara karşı bariyer oluşturarak taşkın hızını keserek azaltmaktadır. Toprak tarafından emilen su, yeraltı suyu olarak depolanmaktadır. Kurak geçen mevsimlerde bitkiler yeraltında depolanan suyu kullanmakta böylece yeraltı su seviyesinin korunumu sağlanmaktadır (Tülek ve Barış, 2014).

\subsubsection{Su tüketiminde tasarruf sağlayan yöntemlerin kullanılması}

Damla sulama sistemleri ve zaman ayarlı kontrollü otomatik sulama sistemleri su tüketiminde tasarruf sağlayan yöntemlerdir. Ancak zaman ayarlı sulama sistemleri belirli bir programa göre çalışmakta ve yağmurlu günlerde çalışarak su israfına neden olmaktadır. Bu nedenle, yağmur ve nem sensörlü akıllı kontrolör ara yüzlü otomatik sulama sistemlerinin kullanılması önerilmektedir (Reed ve Stibolt, 2018). iklim değişikliği ile ani şiddetli yağışlar ile sel ve ani Isı değişimleri sonucu kuraklık meydana gelmektedir. Bu nedenle suyun yönetimi yerel ve kuraklığa dayanıklı bitkilerin kullanımı ile mümkün olabilmektedir. Yerel ve iklime uygun, kuraklığa toleranslı yer örtücü bitki kullanımı su tüketimine katkıda bulunarak tasarruf sağlamaktadır. Ayrıca kentsel alanlardaki gri suyun hasat edilmesi, yeniden kullanılması ve su tüketim verimliliğinin arttırmaktadır.

\subsubsection{Ekosistemin korunması}

Ekosistemin bozulmaması için yapılı çevrenin, doğal çevre ile uyum içinde ve entegre düşünülmesi gerekmektedir. Ekosistemin korunması; katı atıkların geri dönüşümü, atık suların geri dönüşümü, az atık üreten malzemelerin kullanılması ve mevcut bitki örtüsü, su varlığı, flora, fauna gibi doğal kaynakların korunmasını kapsamaktadır.

\subsection{Değerlendirme}

Balıklıgöl Kent Platosu, kent merkezinde önemli bir konumda, yoğun yeşil dokusu, doğal su varlığı ve geleneksel yapılardan oluşan kent dokusu ile özel bir ekolojik değere sahip olup, bu değerin gerek kültürel gerek ekolojik açıdan korunması gerekmektedir. Bu kapsamda Balıklıgöl Kent Platosu'nun ekolojik tasarım kapsamında değerlendirilmesi önem taşımaktadır. Bu bağlamda, enerji etkin tasarım, etkin kaynak kullanımı, etkin su kullanımı ve ekosistemin korunması anlamında çalışma alanı değerlendirilmiştir.

\subsubsection{Balıklıgöl kent platosu'nun enerji etkin tasarım kapsamında değerlendirilmesi}

iklimlendirmenin doğal yöntemlerle sağlanması gerekir.Bu bağlamda Balıklıgöl Kent Platosu; Tel Fettur Tepesi ile Damlacık Tepesi arasında kalan vadi tabanına konumlandırılmış olması nedeni ile bir sıcak kuru iklim kuşağı yerleşmesidir. Vadi tabanlarında aynı zamanda güneş ışınımının ısıtıcı etkisi daha düşüktür. Ayrıca Halilürrahman Gölü, Ayn Zeliha Gölü ve su kanallarının bulunması havayı nemlendirerek doğal serinleme sağlayarak mikroklimatik konfor sağlamakta olup ekolojik açıdan destekleyici bir etki sağlamaktadır. Araştırma alanında gerçekleştirilen uygulamalar gerek yapı gerek açık yeşil alan ve su kullanımları açısından ekolojik tasarım kriterlerine uygun olarak gerçekleştirilmiştir.

Sıcak- kuru iklim kuşağında yer alan yerleşmelerde açık- yarı açık ve kapalı hacim geçişlerinin sağlanması ve bu anlamda avlulu ve revaklı yapılanmanın tercih edilmesi gerek hava sirkülasyonu gerek gölge hacimler oluşturulması açısından önemlidir. Balıklıgöl ve yakın çevresinde yer alan tüm anıtsal ve sivil mimarlık örnekleri avlulu ve revaklı olarak tasarlanmıştır (Şekil 12). Yanı sıra tüm binalar ve yapılar açık sarı renkli ve kireçtaşından oluşur (Turgut ve diğerleri, 2006). Yerel Urfa taşı ile kalın taş duvarlara sahip yapılar olarak inşa edilmiş olup, etkin ısı yalıtımı açık renkli taş duvarlar güneş ışınlarını yansıtarak ekolojik tasarım kriterlerine uygun biçimde yapılandırılmıştır. 


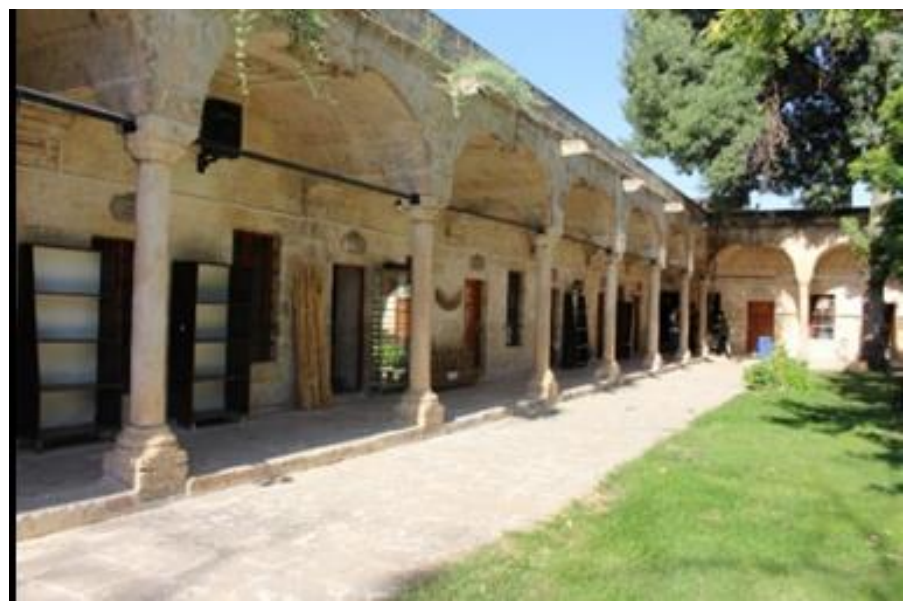

Şekil 12. Rizvaniye Külliyesi avlu ve revak kullanımı

Isıtma, soğutma ve aydınlatma cihazlarını çalıştırmak için gereksinim duyulan enerji kaynaklarının neden olduğu gazlar hava kirliliğine yol açmaktadır. Bu durum karşısında yenilebilir enerji kaynakları önem kazanmaktadır. Yenilenebilir kaynaklardan güneş enerjisi, Şanlıurfa kenti gibi güneşli gün sayısının oldukça fazla olduğu bir kent için en önemli yenilenebilir enerji kaynağıdır. Araştırma alanının genelinde güneş enerjisi ile çalışan aydınlatma elemanının kullanımı doğru planlama ile enerji tüketimini azaltacaktır. Balıklıgöl yakın çevresinde gerçekleştirilen aydınlatmalarda güneş enerjisi ile çalışan aydınlatma elemanları kullanılmamıştır. Ayrıca Balıklıgöl'de aydınlatmaların yerleşimi doğru bir planlama ile yapılmamış olup, aydınlatmaların kullanım alanları oldukça yakın olup, gereksiz boş alanlarda aydınlatılmıştır (Şekil 13). Bu durum ışık yoğunluğu açısından kirlilik yaratacak, flora ve fauna üzerindeki baskıyı da arttırmaktadır. Ana giriş meydanında yüksek aydınlatma elemanları kullanılırken, yürüyüş yaya yolları kenarında alçak aydınlatmalar tercih edilmiştir. Yüksek aydınlatmalar ile 'gökyüzü parlaması' oluşarak, doğal yaşamı olumsuz etkileyerek enerjinin etkin kullanılmamasına neden olmaktadır. Aydınlatmanın ihtiyaç duyulan yere doğru aşağı yönlendirilmesi sağlanarak, LED aydınlatma teknolojisi kullanılması enerji etkinliğini arttırır (Rehan, 2013). Ekolojik tasarım bağlamında; güç kontrolü için güneş enerjili, zaman ayarlı aydınlatmaların kullanılması önemlidir (Alpay ve diğerleri, 2013).

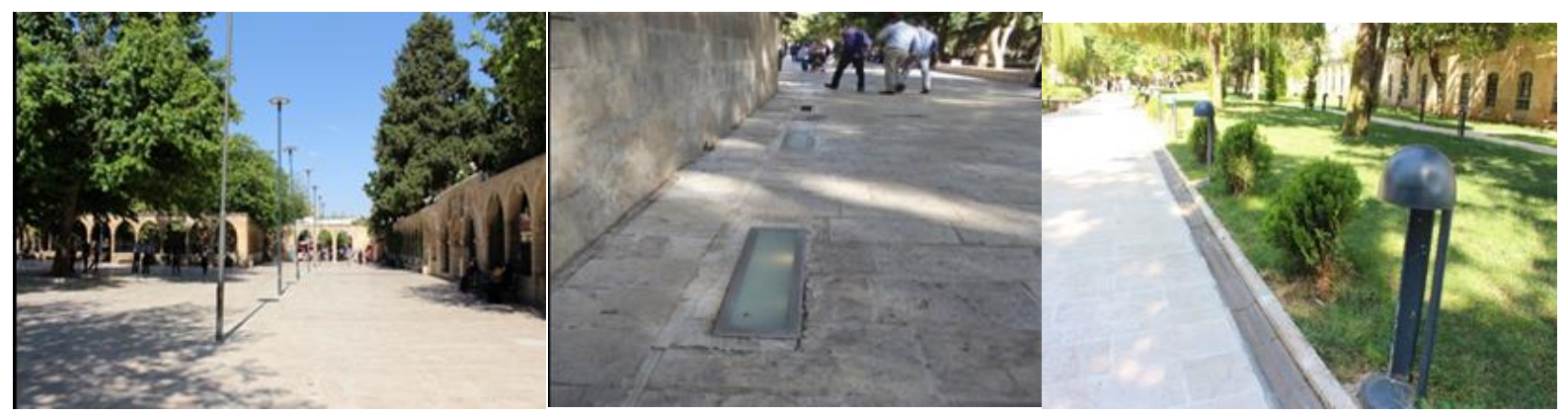

Şekil 13. Balıklıgöl'de kullanılan aydınlatmalar.

Balıklıgöl Kent Platosu'nda kullanılan kiokslar ve suyun döngüsünü sağlayan sağlayan su motorlarının çalışmasında, güneş enerjisi kullanılmamakta olup, enerji etkinliği için güneş enerjisinden yararlanılması ile yenilenebilir enerji kullanımı sağlanmış olacaktır (Şekil 14, 15). Şanlıurfa kenti bu anlamda enerjiyi en etkin kullanma potansiyeline sahip yörelerden biridir. 


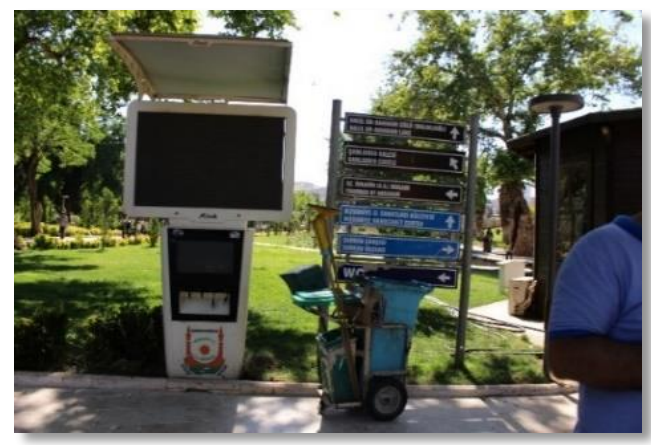

Şekil 14. Balıklıgöl’de kullanılan kiokslar

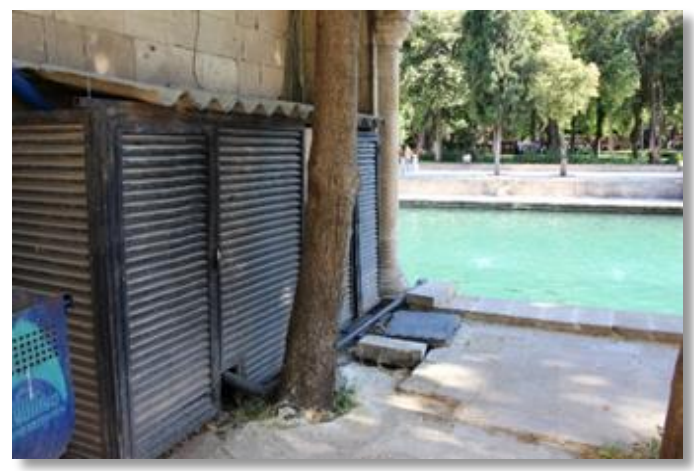

Şekil 15. Su döngüsünü sağlayan su motoru

\subsubsection{Balıklıgöl Kent Platosu'nun etkin kaynak kullanımı kapsamında değerlendirilmesi}

Yerel kaynak ve dayanıklı malzeme kullanımı gerekmektedir.Şanlıurfa yerleşimi ve yakın çevresinde bulunan en önemli yerel ve dayanıklı malzeme Urfa taşıdır. Şanlıurfa kenti doğal yapı malzemesi olan zengin kireçtaşı (Urfa taşı) kaynaklarına sahiptir. Şanlıurfa'da büyük ölçekte ihracat yapan 5 taş ocağı bulunmakta olup, yıllık 31.680 ton işleme kapasitesi bulunmaktadır (Şanlıurfa Ticaret Odası, 2019). Bu kapsamda Şanlıurfa'da 62.212.500 ton görünür kireçtaşı rezervi bulunmaktadır (MTA, 2010). Bu bakımdan yerel yapı gerecine ulaşmak oldukça kolaydır. Disk testere yardımı ile ocaklardan kolay bir şekilde çıkarılan Urfa taşı tasarıma göre istenilen boyut ve formatta kesilerek kullanıma sunulmaktadır. Yerel Urfa taşının kullanımı ile başka bölgelerdeki kaynaklara yapılacak olan müdahele engellenmiş olacak ve kaynak etkinliği sağlanacaktır. Urfa taşı, geleneksel bir malzeme olması, Şanlıurfa tarihi kent dokusu içinde yer alan pek çok yapının bu malzeme ile inşa edilmiş olması ile sosyo-kültürel açıdan sürdürülebilir hemen hemen tüm yapılarda etkin bir biçimde kullanılan, iyi bir yalıtıma sahip olan ve yerel kaynaklardan elde edilebilir; doğadan elde edilme ile üretim enerjisi ve maliyetinin düşük olması, insan sağılı̆ına zarar vermeyen, geri dönüşebilir ve yeniden kullanılabilir olma özellikleri ile de ekolojik açıdan katkı sağlayan sürdürülebilir bir yapı gerecidir.

Şanlıurfa kentinde Urfa kireç taşı ile yapılan ve bugüne kadar ulaşabilen geleneksel yapılar, bu malzemenin oldukça direnci yüksek ve dayanıklı olduğunu göstermektedir. Urfa kireçtaşının diğer doğal taşlara (mermer, traverten ve andezit) göre çevresel ve atmosferik etkilere daha dayanıklı olduğu saptanmıştır.

Bu kapsamda Balıklıgöl Kent Platosu çevresindeki yapılarda, zemin kaplamalarında, korkuluk ve çiçeklilerde, yapısal ögelerde, donatılarda Urfa taşının kullanılması ile kaynak ve enerji verimliliğini esas alan ve atık oluşumunu azaltan, çevreye duyarlı ekolojik tasarım anlayışı benimsenmiştir (Şekil 16).

Aydınlatma, çöp kutusu, oturma birimi gibi kentsel donatı elemanlarında ve yer döşemesinde de yerel ve dayanıklı malzeme olan urfa taşı tercih edilmesi ekolojik bir yaklaşım olabilir (Şekil 17). 


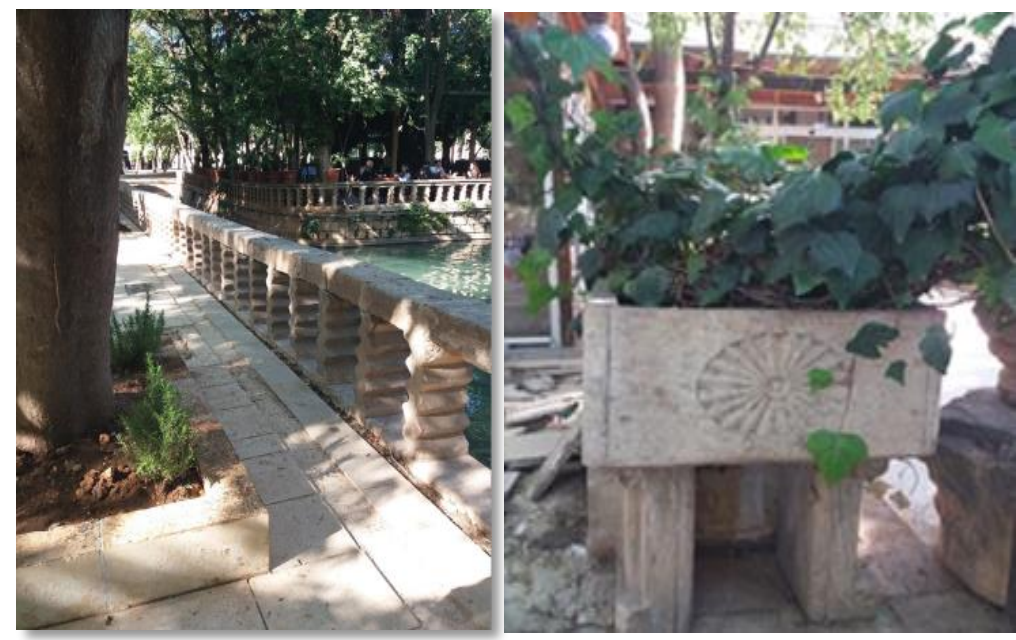

Şekil 16. Balıklıgöl'de korkuluk ve çiçekliklerde Urfa taşı kullanımı (Orijinal, 2021)

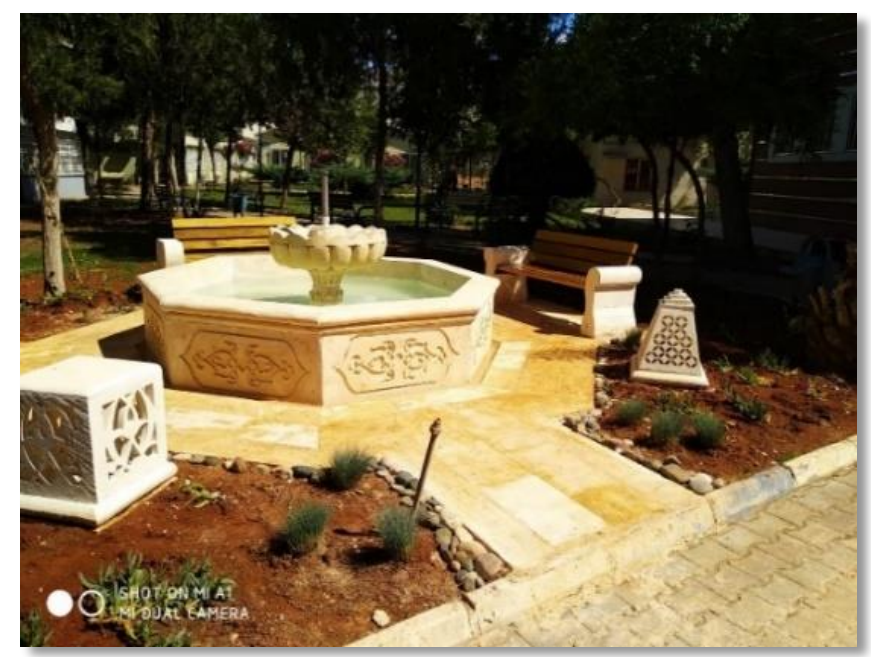

Şekil 17. Urfa taşı ile tasarlanmış kent mobilyaları (Öztürk Tel, 2020)

Balıklıgöl'de döşeme kaplaması olarak yöreden çıkarılan "Urfa taşı" kullanılmıştır. Ancak şu anda yapılan yenileme çalışmalarında yer döşeme malzemesi olarak yerel malzeme olan Urfa taşı yerine Konya'dan getirilen traverten kullanılmaktadır (Şekil 18). Bu durum daha sonra gerçekleştirilen yenileme çalışmalarında yerel malzeme kullanımına önem verilmediğini göstermekte olup sürdürülebilir bir uygulama değildir.
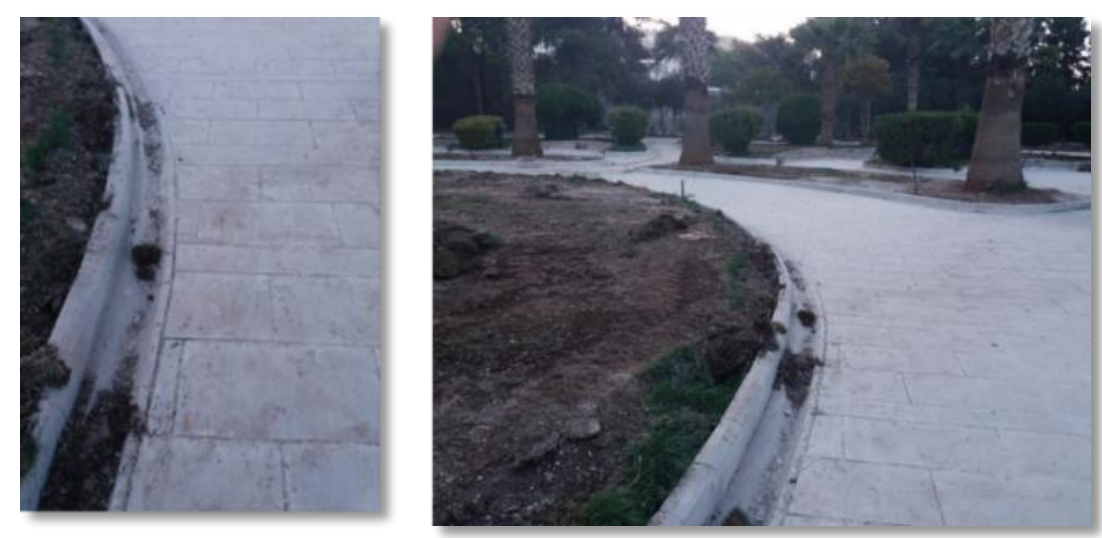

Şekil 18. Son dönemde yapılan çalışmalarda zemin döşeme kaplamalarında kullanılan traverten (Orijinal, 2020)

Demir, çelik, bakır, kurşun, doğal taş gibi maddelerin geri dönüşüm ve tekrar kullanılması, doğal kaynakların tükenmesini önlemektedir. Hurda demirin geri dönüşümü ile ağaç ızgarası ve çöp kutusuna geri dönüşüm sağlanmaktadır (Rehan 2013). Aynı şekilde gerek yapılarda gerek peyzaj tasarımı yapısal 
ögelerinde parçalanan büyük blok taşların küçük parçalara ayırarak uygun yerlerde kullanımı da benzer etki yaratacaktır (Şekil 19).

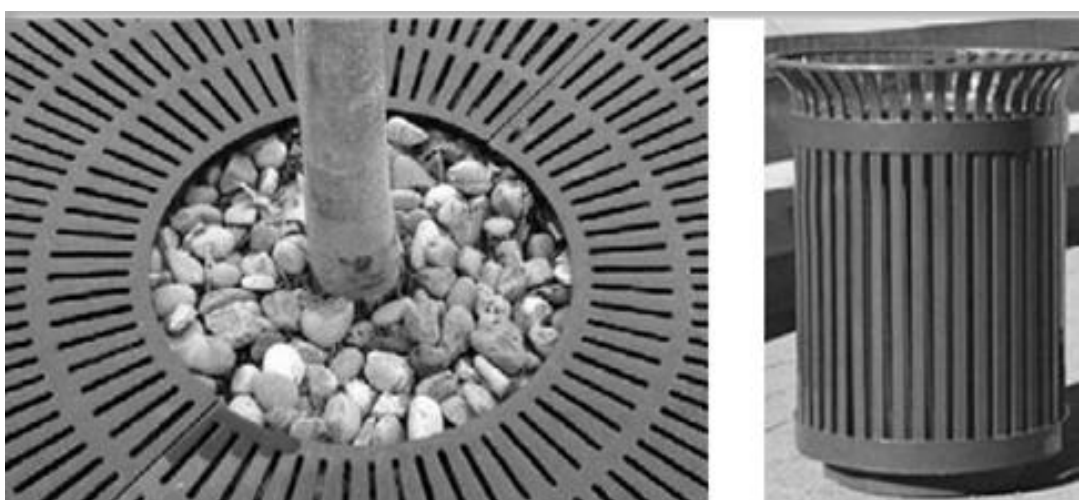

Şekil 19. Geri dönüşümlü hurda demirden ağaç ızgarası ve çöp kutusu (Rehan, 2013)

\subsubsection{Balıklıgöl Kent Platosu'nun etkin su kullanımı kapsamında değerlendirilmesi}

Peyzaj düzenlemelerinde az su isteyen ya da o bölgeye özgü bitkilerin kullanımı, su tüketimini azaltan etkili bir yöntemdir. Yöreye özgü bitki kullanımı estetik ve işlevsel mekanların oluşturulmasında bitkilerin rolü büyük olmakla birlikte sert zeminlerin yumuşatılmasında önemli rolleri bulunmaktadır (Kuter ve Erdoğan, 2010). Özellikle sıcak iklimlerde sert zeminlerin azaltılarak yeşil alanları arttırılması kent içinde ısı adalarının da oluşumunu engellemektedir. Alanda yoğun bitki kullanımı söz konusu olup; yanı sıra mikro klima düzenleyici, tozları filtrelemede ve gürültü kirliliğini azaltmada işlev görmektedir.

Balıklıgöl' de kullanılan bitkilerin listesi verilmiş olup, bu bitkilerden Crataegus monogyna Jacq. (adi alıç) ve Celtis glabrata Steven ex Planch. (çitlembik) Şanlıurfa'da doğal yayılış gösteren türlerdir. Alanda çoğullukla egzotik bitkiler de kullanılmıştır. Mevcut bitkilerin korunarak, yerel bitkiler ile tür çeşitliliği sağlanması ekolojik tasarımın vazgeçilmezidir (Onur ve Demiroğlu, 2016).

Balıklıgöl Kent Platosunda, egzotik Viola tricolor L. (hercai menekşe), Tagetes erecta L. (kadife çiçeği), Celosia argentea (horoz ibiği), Impatiens walleriana Hook.f. (cam güzeli) türü mevsimlik çiçekler kullanılmış olup; bunun yerine yörede doğal olarak bulunan, yöreye özgü mevsimlik ve çok yıllık çiçekler (geofitler) tercih edilerek bakım masrafları azaltılmış olur (Şekil 20, 21, Çizelge 3).

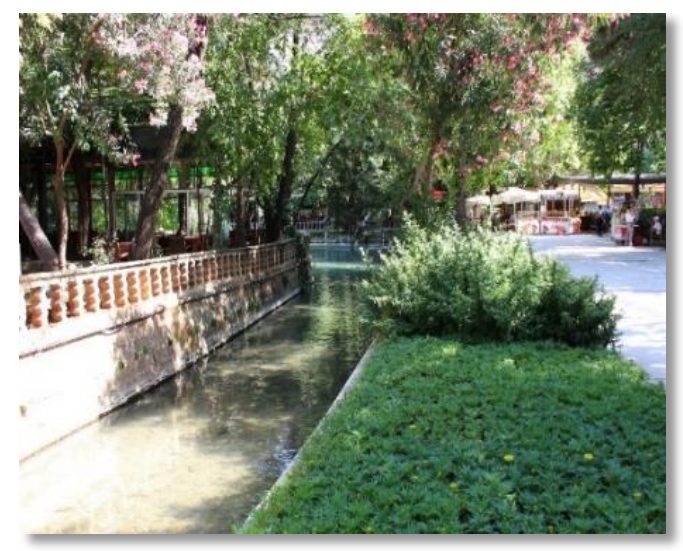

Şekil 20. Egzotik mevsimlik Tagetes erecta 


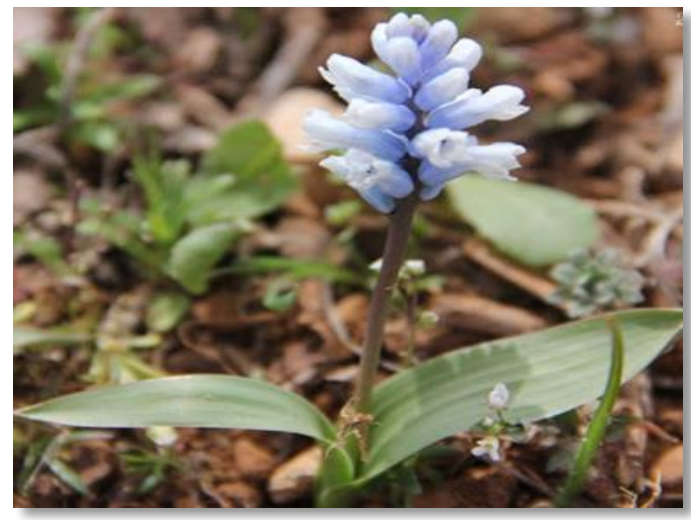

Şekil 21. Doğal yayılış gösteren geofit çiçeğinin kullanımı Hyacinthella siirtensis (Musa Geçit Arşivi, 2021)

Çizelge 3. Şanlıurfa yöresine özgü mevsimlik ve çok yıllık çiçekler (geofitler) (Akan ve diğerleri, 2005).

\begin{tabular}{lll} 
Latince Adı & Türkçe Adı & $\begin{array}{l}\text { Çiçeklenme } \\
\text { Dönemi }\end{array}$ \\
\hline Achillea brachyphylla & Civanperçemi, Akbaş otu & Mayıs \\
\hline Centaurea obtusifolia & Peygamber Çiçeği & Mayıs \\
\hline Centaurea sclerolepis & Peygamber Çiçeği & Mayıs \\
\hline Convolvulus assyricus & Yabani sarmaşı & Mayıs -haziran \\
\hline Convolvulus galaticus & Yabani sarmaşık & Mayıs-Ağustos \\
\hline Crocus leichtlinii & Safran, çiğdem & Mart-Nisan \\
\hline Hesperis hedgei & Akşamsefası & Mayıs \\
\hline Hyacinthella siirtensis & Yabani sümbül & Mart \\
\hline Hypericum capitatum var. Capitatum & Binbir delik otu, kantaron & Nisan-haziran \\
\hline Rosularia haussknechtii & & Mayıs \\
\hline Scilla mesopotomica & Mezopotamya sümbülü & Mart \\
\hline Stachys setifera subsp Iycia & & Mayıs-ağustos \\
\hline Tordylium cappadocicum & & Mayı-haziran \\
\hline
\end{tabular}

Geniş çim alanlarının optimal/etkin kullanımı gereklidir. Balıklıgöl'de kısmen geniş çim alanlara yer verilmiştir (Şekil 22). Geniş çim alanların bakım maliyetleri oldukça fazla olduğundan ve sıcak ve kurak iklimde yer yer sararmalar olduğundan ekolojik bir yaklaşım olarak değerlendirmek olası değildir. Şanlıurfa'da doğal yayılış gösteren, kuraklığa dayanıklı, renk güzelliği olan, çok yıllık yerörtücülerin seçimi ekolojik açıdan doğru bir yaklaşım olacaktır. Bu kapsamda; Acanthus syriacus Boiss., Achillea wilhelmsii K.Koch, Ajuga chamaepitys (L.) Schreb., Linum mucronatum Bertol., Salvia multicaulis Vahl. olarak önerilmektedir (Şekil 23).

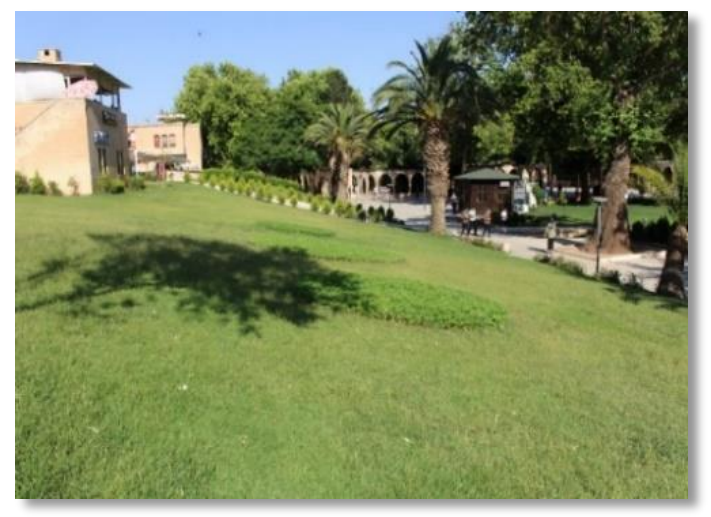

Şekil 22. Alanda bulunan geniş çim yüzeyler 


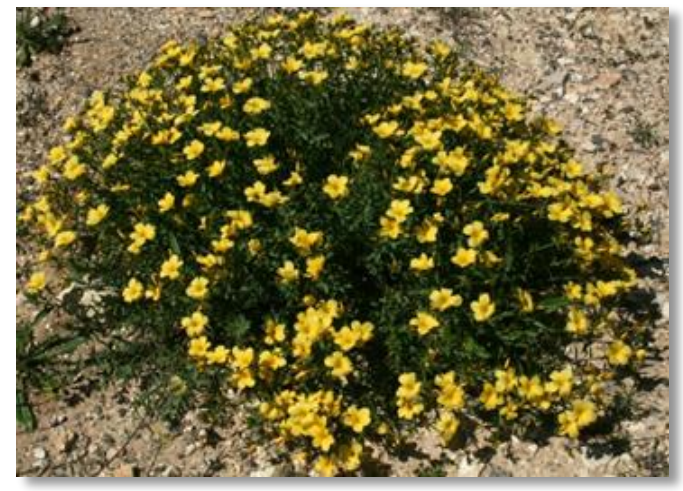

Şekil 23. Doğal yayılım gösteren yer örtücü Linum mucronatum Bertol.

Yağmur suyu toplama sistemlerinin uygulanması gereklidir. Alanda Şanlıurfa Büyükşehir Belediyesi tarafından yağmur suyu boruları ve drenaj sistemi değiştirilmesine rağmen 2017 yılında meydana gelen sel sonucunda biriken çamurlu su Balıklıgöl'de kirliliğe neden olmuştur. Göldeki tıkanan su giderleri tıkanmış ve balıklar zarar görmüştür (Şekil 24) (Virahaber, 2021). Çalışma alanında yüzey akışının toplandığı büyük yeşil alanın ortasına yağmur bahçesi yapılarak, killi toprak ve çakıllar ile kapasitesi arttırılarak taşkın ve sel baskınları engellenebilecek durumdadır (Şekil 25).

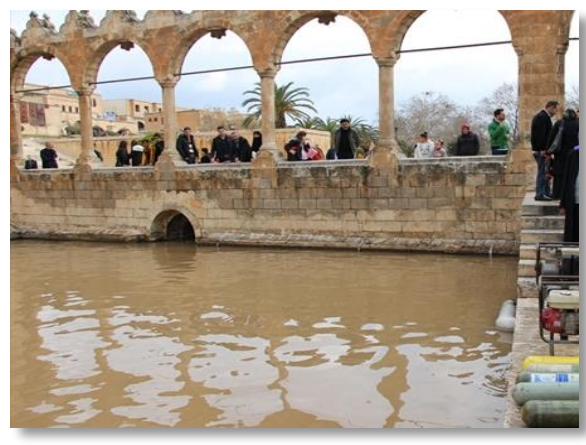

Şekil 24. 2017 sel taşkını sonrası Balıklıgöl

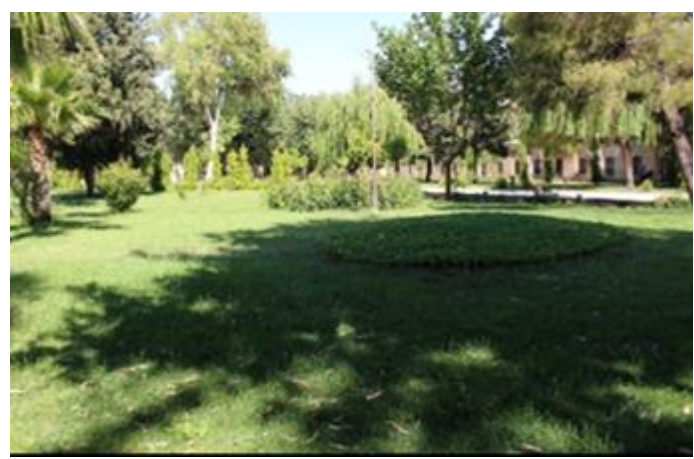

Şekil 25. Balıklıgöl’de yağmur bahçesi yapımı için önerilen alan (Virahaber, 2021).

Yağış suyunu bordür açıklıklarından içine alacak şekilde yol ve kaldırım kenarlarında oluşturulan yağış suyu bitki şeritleri yüzey akış suyu kontrolü sağlarken, sızdırma ve filtreleme işlevlerini de görmektedir

Yer altı su seviyesinin korunması gereklidir. Sert zeminlerde geçirimli malzemelerin kullanılması yer altı suyu seviyesi açısından önemli olduğu için Urfa taşının porozite ve su emme değeri \%9 ile \%16 arasında bulunması nedeni ile geçirimliliği diğer doğal taşlara göre fazla olup, bu anlamda kullanımı son derece doğru ve uygundur.

Yağış suyunu bordür açıklıklarından içine alacak şekilde yol ve kaldırım kenarlarında oluşturulan yağış suyu bitki şeritleri yüzey akış suyu kontrolü sağlayarak yer altı su seviyesinin korunmasına katkı sağlamaktadır. Bu bakımdan alandaki bordürlere yağış suyu bitki şeridi ve bitki ızgarası yapılması önerilmektedir (Şekil 26). 


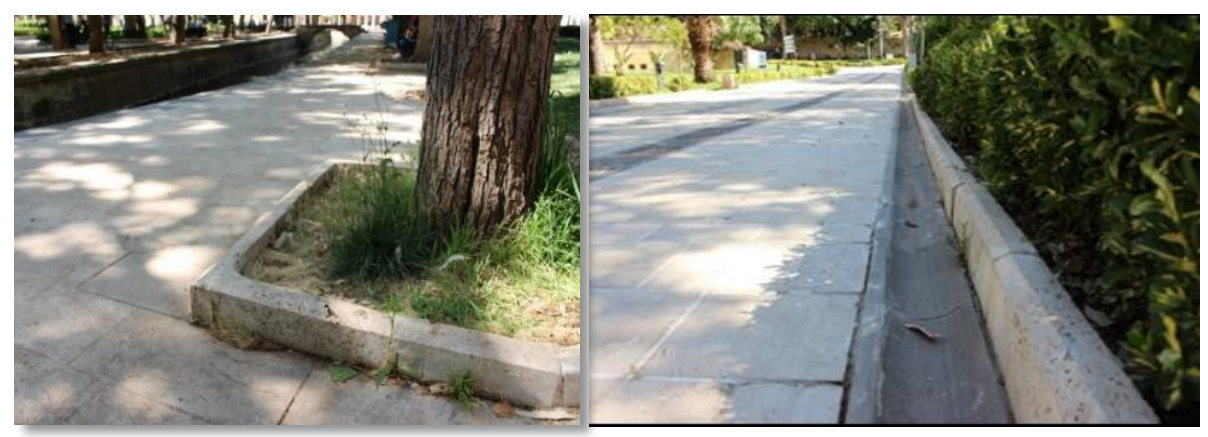

Şekil 26. Bordürlerde yağış suyu bitki şeridinin bulunmaması (Orijinal, 2021).

Su tüketiminde tasarruf sağlayan yöntemlerden damla sulama ve zaman ayarlı kontrollü otomatik sulama sistemleri kullanılmaktadır. Bu sistemler yerine yağmur ve nem sensörlü akıllı kontrolör ara yüzlü otomatik sulama sistemlerinin kullanılması su tüketiminde daha fazla tasarruf sağlayacaktır.

\subsubsection{Balıklıgöl Kent Platosu'nun ekosistemin korunması kapsamında değerlendirilmesi}

Katı atıklarının ayrıştırarak yeniden kullanılmasının sağlanması, atığın azaltılması ve kontrol altında tutulması, atık suların arıtılarak bahçe sulamasında değerlendirilmesi, yapılarda ve kent mobilyalarında seçilen malzemelerin tekrar kullanım ve dönüşüm olanağının olması gerekliliğinden yola çıkılarak bilinerek, gereksiz atık çıkartacak uygulamalardan kaçınılmalı, esnek planlama yapılmalıdır. Alanda bu doğrultuda yapılmış herhangi bir çalışma bulunmamaktadır.

Mevcut bitki örtüsü, su varlığı, flora, fauna gibi doğal kaynakların korunması kapsamında alanda tespit edilen mevcutta yer alan bitkilerin korunması gerekmekte olup, alanın florasına uygun Şanlıurfa da doğal yayılış gösteren yer örtücü türlerin tercih edilmesi floranın korunmasını destekleyerek, su etkin bir tasarım ve uygulama sağlayacaktır.

Alanda yer alan Halil-ür Rahman gölü, Ayn Zeliha gölleri ve kanallar önemli su varlıklarıdır. Mevcut su varlığında zaman zaman kirlenmeler olup, süzgeçler ve su sirkülasyonu ile temizlikleri yapılmaktadır. Bu konuda daha hassas yaklaşılarak ekolojik yöntemlerin uygulanması gerekmektedir. Göllerde bulunan, sazangiller familyasından balık türlerinin korunması ve sürdürülebilirliğinin sağlanması hem ekolojik hem kültürel ve sembolik, hem de somut olmayan kültürel değerler açısından önemlidir. Bu nedenle bu kutsal sayılan balık türlerinin hastalık vb. ölümleri durumunda balıkların çoğaltımları yapılarak kentsel alanda uygun bir konumda akvaryumların yetiştirilmesi hem balıkların sürdürülebilirliğini koruyacak hem de halkın eğitimine katkı sağlayacağından ekolojik bir yaklaşım olacaktır. Balıklıgöl güneyinde yer alan istinat duvarı sınıra akvaryumları yanı sıra sarılıcı doğal bitki türlerine yer verilmesi sert zemini yumuşatarak, mikroklimatik konforu arttırır. Bir bölümüne de kentin tarihi ile ilişkili Urfa taşından rölyeflere yer verilmesi hem ekolojik hem de eğitsel açıdan katkı sağlayacaktır (Şekil 27).

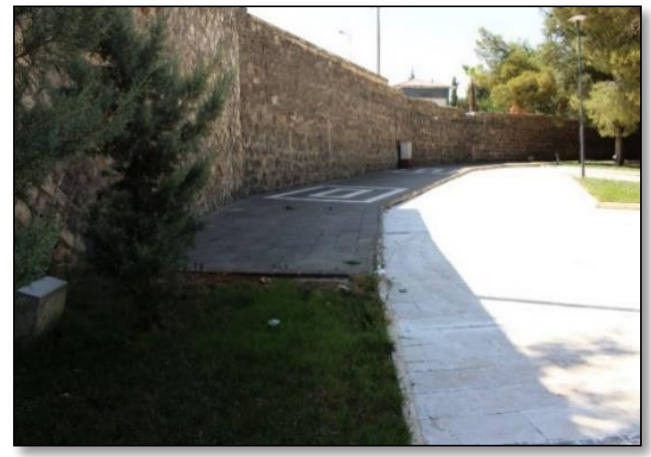

Şekil 27. Akvaryum, sarılıcı bitki ve rölyeflerin uygulanması önerilen duvar yüzeyi (Orijinal, 2021) 


\section{Sonuç ve Öneriler}

Balıklıgöl Kent Platosu tarihi kent dokusu içinde hem doğal hem dini hem de sembolik özellikleri ve değerleri ile eşsiz bir kent parkıdır. Alan ekolojik, geleneksel, estetik ve yapısal değerleri ile geleceğe aktarılması gerekmektedir.

Balıklıgöl Kent Platosu'nun ekolojik tasarım kriterleri kapsamında değerlendirildiğinde kısmen ekolojik tasarım kriterlerine uyum sağladığı kriterlere uyum sağladığı belirlenmiştir. Çeşitli ekolojik restorasyonlarla ekolojik tasarım potansiyelinin artabileceği sonucuna varılmıştır.

Araştıma alanında insan - doğa etkileşimi irdelendiğinde alanın sahip olduğu doğal bileşenlerin oldukça duyarlı değerlendirildiği, doğa uyumlu düzenlendiği görülmektedir. Ancak kullanımdan kaynaklı doğal zararlanmalar nedeni ile küçük ölçekli bazı ekolojik restorasyonlar ile alanın ekolojik potansiyeli arttırılabilecektir.

Alanda genel anlamda yerel iklim koşulları ve kent yaşam kültürü doğrultusunda olabildiğince basit ve doğa uyumlu olarak çözümlenmiştir. Ancak özelde bazı alanlarda detay çözümleri ile ekolojik sürdürülebilirlik desteklenebilecektir.

Balıklıgöl kent parkında yenilenebilir enerji kaynaklarından güneş enerjisinin aydınlatma elemanlarında kullanılması, zemin kaplaması ve kent mobilyalarında malzeme olarak yerel, geri dönüşümlü, dayanıklı ve düşük bakım giderleri olan ekolojik malzeme olan Urfa taşının tercih edilmesi, geniş çim alanların kullanımının azaltılması, yağmur bahçelerine yer verilmesi, atıkları ayrıştıran çöp kovaları vb. uygulamalar ile ekolojik potansiyeli daha da arttıracak önlemler olacaktır.

Balıklıgöl Kent Platosu; 17. ve 19. yüzyıl arası Anadolu uygarlıklarının izlerini taşıyan Şanlıurfa ve Harran yerleşimleri UNESCO'nun Dünya Kültür Mirası listesine aday durumdadır ancak; Balıklıgöl ve yakın çevresinin halen yürürlükte olan ekolojik tabanlı yönetim planının olmaması önemli bir sorun oluşturmaktadır.

Araştırma sonucunda elde edilecek bulguların ekolojik tabanlı alan yönetimi planının hazırlanmasına katkı sağlayacağı düşünülmektedir. Alan yönetim planında; minimum insan müdahalesi gerektiren bakım çalışmalarının yapılması, sürdürülebilir, ekolojik yönetim politikalarının kullanımı, ekolojik anlamda konusunda uzman kişilerin alan yönetimine dahil edilmesi, yönetim ve bakımda yerel halkın gönüllü katılımının sağlanması, kullanıcıların söz sahibi olması gerekmektedir.

Alandaki çevresel koşullar süreç içinde değişmekte, bu nedenle bir bakım planının oluşturularak; düzenli kontroller gerçekleştirilmesi, drenajın sağlanması, doğal yer örtücü bitkilerden Acanthus syriacus Boiss., Achillea wilhelmsii K.Koch, Ajuga chamaepitys (L.) Schreb., Linum mucronatum Bertol., Salvia multicaulis Vahl. türleri önerilmektedir.

Alan içinde su habitatlarının korunması, su kanallarının bulunduğu alanın düzenli bakım ve onarım çalışmaları yapılarak taşkınlara neden olmaması sağlanmalıdır. Göl ve kanallarda düzenli bir filtrasyon sistemi bulunmayıp, bu kapsamda gerekli müdahale sağlanarak etkin uygulamalar gerçekleştirilmelidir.

Mevcut bitki örtüsünün korunarak yöre koşullarına uygun bitkilerin tercih edilmesi, bahçe duvarların Parthenocissus quinquefolia (L.) Planch. (Amerikan sarmaşığı) ile kaplanması, bitki bakımlarının belirli bir periyota göre yapılması gerekmektedir.

Alanın yakın çevresinde yaşayan halk Suriyeli sığınmacılardan oluşmakta olup sosyal ve kültürel yaşam değişim ve dönüşüme uğramış, alanda yoğun bir baskı oluşarak koruma problemi oluşmuştur. Öncelikle bu insanlar, koruma, çevre bilinci, alanın tarihi geçmişi ve kimliği konularında yeterli bilgiye sahip bulunmamaktadır. Ekolojik tasarımın en önemli amaçlarında biri de yerel halkın eğitilerek çevreye daha duyarlı yaklaşmasının sağlanmasıdır. Yapılacak eğitimler ile bu mümkündür. Alan yönetiminde halka verilecek eğitimlerin bir planlama doğrultusunda yapılması gerekmektedir.

Alan bütüncül olarak ele alınmalı; zorunlu durumlarda gerçekleştirilen parçacıl müdahaleler bütüne entegre edilmelidir. Balıklıgöl Kent Platosu'nda gerçekleştirilen tasarım yaklaşımı estetik açıdan da yerel geleneksel doku ile uyumlu ve bütüncül olmalıdır. Balıklıgöl Kent Platosu'nun taşıdığı soyut ve somut kültür değerleri, doğal varlığı ve dini, sembolik, manevi içeriği ile son derece özgün ve geleneksel 
kimliğini korumasından kaynaklı olarak büyük ölçüde ekolojik tasarım kriterlerine göre tasarlanmış, önemli bir miras alanı olarak gelecek kuşaklara aktarılması gereken eşsiz bir kentsel kamusal alandır.

\section{Teşekkür ve Bilgi Notu}

Makalede, ulusal ve uluslararası araştırma ve yayın etiğine uyulmuştur. Çalışmada etik kurul izni gerekmemiştir.

\section{Yazar Katkısı ve Çıkar Çatışması Beyan Bilgisi}

Makalede tüm yazarlar aynı oranda katkıda bulunmuştur. Herhangi bir çıkar çatışması bulunmamaktadır.

\section{Kaynaklar}

Akan, H., Eker, i. ve Balos, M. Maruf. (2005). Şanlıurfa'nın Nadide Çiçekleri (Geofitler), Şanlıurfa Belediyesi yayınları. Şanlıurfa.

Alpay, C. O., Kalaycı, A. ve Birişçi, T. (2013). Ekolojik Tasarım Kriterlerine Göre Kent Parkı İyileştirme Modeli: İzmir Kültürpark Örneği. TMMOB İzmir, 2, 328-343.

Coşkun Hepcan, Ç. (2019). Kentlerde İklim Değişikliği ile Mücadele için Yeşil Altyapı Çözümleri. İklim Değişikliği Eğitim Modülleri Serisi, İklim Değişikliği Alanında Ortak Çabaların Desteklenmesi Projesi (iklinIN), Ankara.

Cranz, G. ve Bol, M. (2003). The ecological park as an emerging type. Places 15, 44-47.

Ekinci, A. ve Paydaş, K. (2008). Taş Devrinden Osmanlı'ya Urfa Tarihi. Şanlıurfa Valiliği.

Eryıldız, S. (1995). Ekokent: Çevreyi geliştirici kentleşme. Gece Yayınları.

Gelener, M. A. (2011). Şanlıurfa ili tarihi su yapılarının belirlenmesi ve teknik özellikleri/Determining of historical water constructions in Şanliurfa and technical properties of these structures (Doctoral dissertation).

Girginer, S. (2006). Kentsel tasarım ile ekolojik sürdürülebilirliğin ilişkilendirilmesi ve toplu konut gelişme bölgelerinde örneklenmesi. Dokuz Eylül Üniversitesi Fen Bilimleri Enstitüsü, İzmir.

Güzel, A. (2020). Natural features geography of Şanlıurfa province. The Journal of International Social Research, 13 (71):195-2015.

Jaber, F., Woodson, D., LaChance, C. ve York, C. (2012). Stormwater Management: Rain Gardens, The Department of Soil and Crop Sciences and Texas A\&M Agri Life Communications, The Texas A\&M System,USA, p. 20.

Jayasuriya, L. N. N., Kadurupokune, N., Othman, M. ve Jesse, K. (2007). Contributing to the sustainable use of stormwater: the role of pervious pavements. Water Science and Technology, 56 (12), 6975.

Karacadağ Kalınma Ajansı. (2018). İstatistiklerle Şanlıurfa. Erişim adresi (17.07.2021): https://www.karacadag.gov.tr/Dokuman/Dosya/www.karacadag.gov.tr_306_FO6F86VU_istati stiklerle_sanliurfa_2018.pdf.

Kuter, N. ve Erdoğan, E. (2010). Çankırı kentsel sit alanının bitki varlığı açısından değerlendirilmesi. Tekirdağ Üniversitesi, Ziraat Fakültesi Dergisi. 7 (2): 105.

Manisalı, N. (2011). Ekolojik Yerleşimler Üzerine Bir Değerlendirme, İstanbul'dan Örnekler. T.C. Gebze Yüksek Teknoloji Enstitüsü Mühendislik ve Fen Bilimleri Enstitüsü. Gebze.

MTA. (2010). Erişim adresi (28.01.2010): Maden Tetkik ve Arama Genel Müdürlüğü. Güneydoğu Anadolu Bölgesi Maden Envanteri. http://www.mta.gov.tr/v1.0/bolgeler/diyarbakir/index.php?id=gdab_maden_envanteri_made $\mathrm{n} \& \mathrm{~m}=4$, Diyarbakır. 
Musa geçit Arşivi (2021). Erişim adresi (02.07.2021): http://dogalhayat.org/property/hyacinthellasiirtensis.

$\mathrm{Ni}$, J. (2019). The Effect of Green Space Plant Ecological Landscape Design on the Purification of Urban Ecological Environment. Ekoloji, 28(108), 1499-1503.

Olsson, I. (2018). In search of sustainable urban green infrastructure through an ecological approach. Division of Landscape Architecture Master's thesis at the Landscape Architecture programme, 30 HEC, Uppsala

Onur, B. E. ve Demiroğlu, D. (2016). Kentsel sürdürülebilir mekânlar: Ekolojik parklar. Journal of the Faculty of Forestry Istanbul University, 66(1), 340-355.

Oral, K. G. ve Manioğlu, G., (2005). Iklimle Dengeli Tasarım: Mardin, Antakya, TASARIM, 157, s.136142, Ankara.

Öztürk Tel, H. (2020). Design of Unique Urban Furniture in Outdoor Campus Areas, Online Journal of Art and Design, 8(4), 68-83.

Paulsen, J. (2001). Life Cycle Assessment for Building Products-The significanse of the usage phase (Doctoral dissertation, Institutionen för byggnader och installationer).

Reed, S. ve Stibolt, G. (2018). Climate-wise Landscaping: Practical Actions for a Sustainable Future. New Society Publishers.

Rehan, R. M. (2013). Sustainable streetscape as an effective tool in sustainable urban design. Hbrc Journal, 9(2), 173-186.

Saltabaş, F., Tombul, B., Yazgan, M. Z. ve Yüksel, F. (2012). Tehlikeli atık yönetimi ve bertaraf teknolojileri. Tehlikeli Atık Yönetimi Eğitimi, İstanbul, Türkiye, 28.

Şahinalp, M. S. (2005). Şanlıurfa Şehri'nin kuruluş ve gelişmesi. Ankara Üniversitesi Sosyal Bilimler Enstitüsü. Ankara.

Şanlıurfa Büyükşehir Belediyesi. (2019). Balıklıgöl Alan Yönetim Planı Nihai Rapor (2019-2023).

Şanlıurfa Ticaret Odası. (2019). Şanlıurfa Ticaret Odası 2019 verileri. Sözlü Görüşme.

Şanlıurfa Turizm Master Planı 2019-2023. (2019). Sürdürülebilir Turizm Politikası ve Stratejik Eylem Çerçevesi Şanlıurfa Turizm Master Planı 2019-2023, Vizyon 2030 Şanlıurfa'da Tarih Yeniden Canlanıyor Projesi GAP Turizm Master Planı. Erişim adresi (02.07.2021): https://sutb.org.tr/upload/Dosya/TurizmA\%C5\%9F.pdf

Turgut, P., Yeşilnacar, M. İ. ve Bulut, H. (2006). Yapı malzemesi olarak Urfa Taşı'nın mekanik, fiziksel ve teknolojik özelliklerinin tespiti. TÜBITAK-MAG Projesi (104I084).

Tülek, B. ve Barış, M. E. (2014). Kent içi ve yakın çevresindeki su kıyısı rekreasyon alanlarının ekolojik kriterler açısından değerlendirilmesi: Mavi Göl örneği. Uludağ Üniversitesi Ziraat Fakültesi Dergisi, 28(2), 13-26.

$\begin{array}{llll}\text { Urbanwater (2021). Erişim } & \text { (02.07.2021): }\end{array}$ http://urbanwater.melbourne.vic.gov.au/industry/treatment-types/what-is-a-raingarden/.

Virahaber (2021). Erişim adresi (02.07.2021): https://www.virahaber.com/tarihi-balikligoldekitemizlik-calismasi-devam-ediyor-43968h.htm.

Yang, Y. L. (2017). Application of Sponge City Concept in the Green Corridor Landscape Project of the Outer Cityof Aviation New Town. Flowers (8):33-35.

Yüksek, í. (2008). Geleneksel Anadolu Mimarlığında ekolojik uygulamalar üzerine bir araştırma (Kırklareli kırsal alan örneği) (Yayınlanmamış doktora tezi), Trakya Üniversitesi, Türkiye. 